\title{
Modelling short-term variability in carbon and water exchange in a temperate Scots pine forest
}

\author{
M. H. Vermeulen ${ }^{1}$, B. J. Kruijt ${ }^{1,2}$, T. Hickler ${ }^{3,4,5}$, and P. Kabat ${ }^{1,6}$ \\ ${ }^{1}$ Wageningen University, Department of Earth System Science, Wageningen, the Netherlands \\ ${ }^{2}$ Alterra, Wageningen UR, Climate Change and Adaptive Land and Water Management, Wageningen, \\ the Netherlands \\ ${ }^{3}$ Biodiversity and Climate Research Centre (BiK-F), Senckenberganlage 25, 60325 Frankfurt am Main, \\ Germany \\ ${ }^{4}$ Goethe University, Department of Physical Geography, Altenhöferallee 1, 60438 Frankfurt am Main, Germany \\ ${ }^{5}$ Senckenberg Gesellschaft für Naturforschung, Senckenberganlage 25, 60325 Frankfurt am Main, Germany \\ ${ }^{6}$ International Institute for Applied Systems Analysis, Laxenburg, Austria
}

Correspondence to: M. H. Vermeulen (marleen.vermeulen@wur.nl)

Received: 17 June 2014 - Published in Earth Syst. Dynam. Discuss.: 11 February 2015

Revised: 19 June 2015 - Accepted: 26 June 2015 - Published: 30 July 2015

\begin{abstract}
The vegetation-atmosphere carbon and water exchange at one particular site can strongly vary from year to year, and understanding this interannual variability in carbon and water exchange ( $\left.\operatorname{IAV}_{\mathrm{cw}}\right)$ is a critical factor in projecting future ecosystem changes. However, the mechanisms driving this $\mathrm{IAV}_{\mathrm{cw}}$ are not well understood. We used data on carbon and water fluxes from a multi-year eddy covariance study (1997-2009) in a Dutch Scots pine forest and forced a process-based ecosystem model (Lund-Potsdam-Jena General Ecosystem Simulator; LPJ-GUESS) with local data to, firstly, test whether the model can explain $\mathrm{IAV}_{\mathrm{cw}}$ and seasonal carbon and water exchange from direct environmental factors only. Initial model runs showed low correlations with estimated annual gross primary productivity (GPP) and annual actual evapotranspiration (AET), while monthly and daily fluxes showed high correlations. The model underestimated GPP and AET during winter and drought events. Secondly, we adapted the temperature inhibition function of photosynthesis to account for the observation that at this particular site, trees continue to assimilate at very low atmospheric temperatures (up to daily averages of $-10^{\circ} \mathrm{C}$ ), resulting in a net carbon sink in winter. While we were able to improve daily and monthly simulations during winter by lowering the modelled minimum temperature threshold for photosynthesis, this did not increase explained $\mathrm{IAV}_{\mathrm{cw}}$ at the site. Thirdly, we implemented three alternative hypotheses concerning water uptake by plants in order to test which one best corresponds with the data. In particular, we analyse the effects during the 2003 heatwave. These simulations revealed a strong sensitivity of the modelled fluxes during dry and warm conditions, but no single formulation was consistently superior in reproducing the data for all timescales and the overall model-data match for $\mathrm{IAV}_{\mathrm{cw}}$ could not be improved. Most probably access to deep soil water leads to higher AET and GPP simulated during the heatwave of 2003. We conclude that photosynthesis at lower temperatures than assumed in most models can be important for winter carbon and water fluxes in pine forests. Furthermore, details of the model representations of water uptake, which are often overlooked, need further attention, and deep water access should be treated explicitly.
\end{abstract}




\section{Introduction}

Carbon and water fluxes at one particular site can strongly vary from year to year (e.g. Goulden et al., 1996; Yamamoto et al., 1999; Baldocchi et al., 2001). This interannual variability in net ecosystem exchange (NEE) and actual evapotranspiration (AET) is observed across different geographical regions and ecosystem types, and understanding interannual variability in carbon and water fluxes $\left(\mathrm{IAV}_{\mathrm{cw}}\right)$ is crucial for projections of future ecosystem changes and feedbacks on climate. However, little is known about the processes determining this year-to-year variation. Numerous studies have tried to relate $I_{A V} V_{c w}$ to climatic variables and local ecosystem responses to droughts, fires, and deforestation (e.g. Goulden et al., 1996; Yamamoto et al., 1999; Aubinet et al., 2002; Hui et al., 2003; Williams et al., 2008; Sierra et al., 2009; Weber et al., 2009; Yuan et al., 2009), but no clear picture has yet emerged.

Process-based biogeochemical and vegetation models capture the response of terrestrial ecosystems to mean climatic drivers reasonably well at diurnal and seasonal timescales, but not at yearly and longer timescales (Keenan et al., 2012). At the global scale, some vegetation models reproduce interannual variability in terrestrial net primary production and atmospheric $\mathrm{CO}_{2}$ growth rates well (Peylin et al., 2005; Ahlström et al., 2012; Sitch et al., 2015), but large uncertainty exists at smaller spatial scales. Only few studies have quantified the extent to which these models can reproduce observed $\mathrm{IAV}_{\mathrm{cw}}$ at the regional and site scale (Peylin et al., 2005; Keenan et al., 2012). Despite the uncertainties, such models are widely used to project future changes in vegetation and ecosystem functioning. Some of these model simulations suggest the potential for severe vegetation changes across major global biomes in the future: for example, Amazon forest die-back/greening, as well as substantial shifts in potential natural vegetation distributions for boreal and Mediterranean forests (e.g. Lenton et al., 2008; Rammig et al., 2010; Hickler et al., 2012), and alternative vegetation states under elevated atmospheric $\mathrm{CO}_{2}$ (e.g. Higgins and Scheiter, 2012). Such vegetation changes would also feed back to regional and global climate (e.g. Cox et al., 2000; Naeem, 2002; Sitch et al., 2003; van den Hurk et al., 2003; Arora and Boer, 2005; Bonan, 2008; Pitman et al., 2009; Wramneby et al., 2010), and can affect the long-term terrestrial carbon balance profoundly. Therefore it is crucial that these models accurately reproduce $\mathrm{IAV}_{\mathrm{cw}}$ across all spatial scales.

To provide insight into the climate change impacts on the terrestrial carbon balance in the long term, both shortand long-term vegetation responses to a constantly changing environment should be better understood and represented. This implies better model representations of indirect shortterm processes such as the mechanisms governing vegetation phenology (Cleland et al., 2007; Kramer and Hänninen, 2009; Wolkovich et al., 2012), dynamic carbon and nutrient allocation (Litton et al., 2007; Epron et al., 2012; Franklin et al., 2012), photosynthetic temperature acclimation (Gea-Izquierdo et al., 2010), as well as better representations of indirect long-term processes such as soil, nutrient and carbon dynamics. Before addressing these complex process representations within models, however, it can be useful to test whether $I_{\mathrm{A}} \mathrm{V}_{\mathrm{cw}}$ can be explained by rather simple relationships with direct environmental drivers, such as drought, temperature, and radiation, which can affect, e.g. photosynthesis and soil respiration very directly and instantaneously. Factorial experiments with a dynamic vegetation model can then be used to generate hypotheses concerning simple and/or complex interactions of processes driving $\mathrm{IAV}_{\mathrm{cw}}$. These vegetation models can be expected to capture at least some of the complexity of real ecosystems, and the factorial experiments can be used, for example, to keep certain environmental drivers constant (i.e. switching of their effect, e.g. Hickler et al., 2005) or to implement different hypotheses concerning the most important processes within an ecosystem. The latter can also be achieved by datamodel intercomparisons with several models that differ in their process representation (e.g. Medlyn et al., 2015). In this study, the factorial model experiments refer to model setups with different process representations. With this purpose in mind, we used a long time series of eddy covariance measurements at a well-researched forest site (Loobos, a Scots pine forest on sandy soils in the Netherlands) and a dynamic global vegetation model, DGVM (Lund-Potsdam-Jena General Ecosystem Simulator, LPJ-GUESS; Smith et al., 2001), parameterised for the site. The observed interannual variability in NEE at Loobos is comparable to that found at sites with similar vegetation composition and climate (Carrara et al., 2003), but this interannual variability cannot be explained directly from climate variables (Jacobs et al., 2009; Kruijt et al., 2009). Previous analyses suggest that temperature is an important driver of ecosystem respiration at this site, and the remaining variation could be related to local extremes, such as drought, storm damage, and snowfall in winter (Moors et al., 2015). Luyssaert et al. (2007) thoroughly analysed observational Loobos data and proposed that photosynthesis variability is the main driver of interannual variability in NEE, suggesting that short-term ecophysiological responses play an important role.

In this study, we first tested whether LPJ-GUESS can reproduce the observed $\mathrm{IAV}_{\mathrm{cw}}$ and seasonal carbon and water exchange at the Loobos site from direct environmental factors only. LPJ-GUESS combines detailed vegetation demographics and dynamics with mechanistic representations of short-term plant physiological processes. This combination makes the model a good platform to study $\mathrm{IAV}_{\mathrm{cw}}$ because we can simultaneously study the effects of environmental and ecosystem drivers on modelled $\mathrm{IAV}_{\mathrm{cw}}$. Secondly, we tested whether using alternative model formulations and parameters can explain model error for this single site. We performed these secondary tests because in the first test we observed 
systematic biases during winter periods and drought events. Therefore, we analysed the photosynthesis response to temperature during winter periods, and we analysed the response to drought events by comparing alternative plant water uptake parameterisations.

\section{Methods}

\subsection{Study site and observational data sets}

\subsubsection{Study site}

Loobos $\left(52^{\circ} 10^{\prime} 04^{\prime \prime} \mathrm{N}, 05^{\circ} 44^{\prime} 38^{\prime \prime} \mathrm{E}\right)$ is a planted Scots pine forest that is approximately 100 years old and located in bare sandy soil at the Veluwe forest in the central Netherlands. The dominant tree species is Pinus sylvestris and understory vegetation consists mostly of the grass Deschampsia flexuosa and mosses. Vaccinium myrtillus and various species of lichen make up the remaining understory vegetation, and the site "suffers" from encroachment of Prunus serotina. The landscape consists of vegetated sand dunes that create a bumpy topography with elevations varying by several metres; the local groundwater levels are strongly influenced by this local topography (Moors, 2012). The average tree height is approximately $17 \mathrm{~m}$, and tree density is $478 \mathrm{ha}^{-1}$. For more information on the site, and a complete overview of its measurement instrumentation and description, see http://climatexchange.nl/sites/loobos/, Dolman et al. (2002), Schelhaas et al. (2004) and Elbers et al. (2011).

\subsubsection{Eddy covariance data}

Eddy covariance (EC) and meteorological measurements have been continuously collected at this site since 1995 and these data are part of the FLUXNET database (Baldocchi et al., 2001). EC instrumentation is positioned on a mast extending $3 \mathrm{~m}$ above a $23 \mathrm{~m}$ scaffolding tower. In addition to $\mathrm{EC}$ and meteorological measurements, $\mathrm{CO}_{2}$ concentrations are measured at five levels in the canopy: 24.4, 7.5, 5.0, 2.5 and $0.4 \mathrm{~m}$ above ground. The tower footprint stretches to several hundred metres, while the forest extends for more than $1.5 \mathrm{~km}$ in all directions from this point. EC data are processed to half-hourly corrected fluxes with the instrumentation and method described in Elbers et al. (2011). These data are quality checked, flagged and, if necessary, gap filled and split up in gross primary productivity (GPP) and ecosystem respiration $\left(R_{\text {eco }}\right)$, using the online EC gap-filling and flux partitioning tool at http://www.bgc-jena.mpg.de/ MDIwork/ eddyproc/ (7 April 2014). We used this gap-filled data set to calculate all EC and meteorological variables on a daily time step. Flux partitioning of measured NEE to estimate GPP follows Reichstein et al. (2005), i.e. GPP $=R_{\text {eco }}-$ NEE. Since our data set follows the standard FLUXNET database format, $R_{\text {eco }}$ and GPP are both positive quantities, whereas negative NEE represents a net carbon uptake by the vegetation. As a result, GPP estimates can have a negative sign in this data set and represent a net carbon loss of the vegetation. By definition, negative GPP cannot occur in a biological sense, but negative GPP values were not omitted from the data set to preserve original scatter.

\subsubsection{Additional site data}

Sap flow measurements on Pinus sylvestris are available for 1997 and 1998 using tissue heat balance systems (details in Moors et al., 2012), and for 2009 using Granier thermal dissipation probes. Soil moisture data are available for all years considered within this study (1997-2009), and measured with frequency domain sensors at five different depths: $0.03,0.10,0.25,0.75$ and $2.0 \mathrm{~m}$. In 2005, all sensors were replaced and positioned at different depths: 0.00 (above ground litter), $0.03,0.20,0.50$ and $1.0 \mathrm{~m}$. For comparison with model data, available soil moisture (excluding the litter sensor) was averaged for an upper soil layer $(0-50 \mathrm{~cm})$ and a lower layer $(50-150 \mathrm{~cm})$. Additional site measurements at less frequent intervals include the leaf area index (LAI) of trees and, to a lesser extent, the understory.

\subsection{Model description}

LPJ-GUESS (Smith et al., 2001) is a flexible, modular modelling platform to simulate vegetation dynamics and biogeochemical cycles from local to global scales. It combines mechanistic representations of physiological and biogeochemical processes from LPJ-DGVM (Sitch et al., 2003), with the more detailed descriptions of vegetation dynamics and vegetation structure of forest gap models (FORSKA, Leemans and Prentice, 1989). The model version used in this study includes an improved hydrological scheme (Gerten et al., 2004) and an adaption for European vegetation which is mainly based on dominant tree species rather than plant functional types (PFTs) (Hickler et al., 2012). Vegetation growth is simulated on patches of $1000 \mathrm{~m}^{2}$, where neighbouring tree individuals compete for space, light, and water. On a patch, each tree individual is simulated, but individuals of the same age class (cohort) are identical. Several replicate patches (here 100) are calculated to characterise vegetation over a larger area and account for stochastic processes (establishment, mortality and disturbance events). The model is driven by daily values of temperature, precipitation, and radiation, and information on atmospheric $\mathrm{CO}_{2}$ concentrations and soil texture. The daily calculations of carbon and water fluxes between vegetation and atmosphere are mechanistically simulated in one "canopy exchange" module.

\subsubsection{Photosynthesis calculation}

Photosynthesis - with a distinction between $\mathrm{C}_{3}$ and $\mathrm{C}_{4}$ plants - is based on the original scheme proposed by Farquhar, as simplified by Collatz et al. (1991, 1992), and adapted from the BIOME3 model (Haxeltine and Prentice, 1996a, b). Daily 
gross and net leaf-level daytime photosynthesis are calculated as a function of atmospheric $\mathrm{CO}_{2}$ concentrations, air temperature, photosynthetically active radiation (PAR), day length, and canopy conductance. APAR, the fraction of absorbed PAR captured by the vegetation, is calculated from the leaf area index with Beer's law. Leaf respiration linearly scales with Rubisco enzyme capacity. In the absence of water stress, photosynthesis is limited by two main processes that co-vary: the response of photosynthesis to $\operatorname{APAR}\left(J_{\mathrm{e}}\right)$ and the limitation of photosynthesis by Rubisco enzyme activity and $\mathrm{CO}_{2}\left(J_{\mathrm{c}}\right)$. The rate of carbon assimilation linearly scales with APAR until maximum Rubisco activity is reached. Maximum Rubisco activity is calculated daily under the assumption that sufficient leaf nitrogen is available at the point that the marginal cost by respiration of enhanced carbon gain is zero. This also leads to Rubisco activity itself being proportional to daily APAR (the optimality hypothesis, Haxeltine and Prentice, 1996a). Two environmental stressors that can directly affect modelled daily photosynthesis are temperature and water availability. These are discussed in more detail below.

\subsubsection{Temperature dependence of photosynthesis}

The parameters governing maximum carboxylation capacity $\left(V_{\mathrm{m}}\right)$, as well as parameters describing saturation of $\mathrm{Ru}-$ bisco, oxygen consumption and photorespiration, follow enzyme kinetics and are thus temperature dependent. In addition, when water is not limiting, photosynthesis is made temperature dependent through a temperature scalar function (Fig. 1, see Sitch et al., 2008; function ftemp in Sitch et al., 2003):

$t_{\mathrm{scalar}}=\frac{1-0.01 e^{4.6 /\left(\mathrm{pstemp}_{\max }-\mathrm{pstemp}_{\mathrm{high}}\right)\left(T_{\mathrm{c}}-\mathrm{pstemp}_{\text {high })}\right.}}{1+e^{\left(k_{1}-T_{\mathrm{c}}\right) /\left(k_{1}-\mathrm{pstemp}_{\min }\right) \cdot 4.6}}$

with

$k_{1}=\left(\mathrm{pstemp}_{\min }+\mathrm{pstemp}_{\mathrm{low}}\right) / 2$.

$t_{\text {scalar }}$ (unitless) is a temperature inhibition function that limits photosynthesis at low and high temperatures, where $T_{\mathrm{c}}$ is the daily atmospheric temperature. This scalar is used for the calculation of light-limited photosynthesis $\left(J_{\mathrm{e}}\right)$ and carboxylation-limited photosynthesis $\left(J_{\mathrm{c}}\right)$ through parameter $c_{1}$ (Eq. 11 in Haxeltine and Prentice, 1996b):

$c_{1}=\alpha \cdot t_{\text {scalar }} \cdot \frac{\left(c_{\mathrm{i}}-\Gamma_{*}\right)}{\left(c_{\mathrm{i}}+2 \Gamma_{*}\right)}$ (from Sitch et al., 2003, Eq. 17),

where $\alpha$ is the effective ecosystem-level quantum efficiency, $c_{\mathrm{i}}$ the intercellular partial pressure of $\mathrm{CO}_{2}$, and $\Gamma^{*}$ the $\mathrm{CO}_{2}$ compensation point (further explanation and equations in Sitch et al., 2003). $t_{\text {scalar }}$ is defined with a PFT/speciesspecific lower and upper limit for photosynthesis (pstemp $p_{\min }$, pstemp $_{\max }$ ) and an optimum temperature range (pstemp ${ }_{\text {low }}$, pstemphigh) (Larcher, 1980; Table 3.7). This optimum range

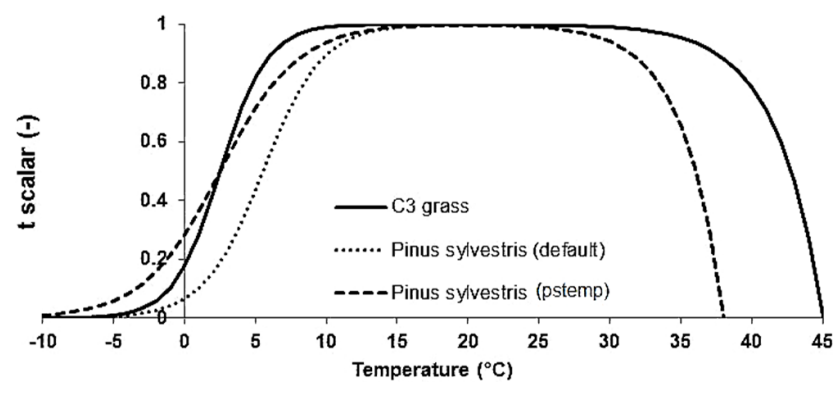

Figure 1. Temperature function $\left(t_{\mathrm{scalar}}\right)$ for Pinus sylvestris and $\mathrm{C}_{3}$ grass, values between 0 (photosynthesis maximally limited by temperature scalar) and 1 (photosynthesis not limited by temperature scalar). Default settings for $P$. sylvestris (dotted line: pstemp $p_{\min }=-4{ }^{\circ} \mathrm{C}$, optimum $15-25^{\circ} \mathrm{C}$, pstemp $p_{\max }=37^{\circ} \mathrm{C}$ ) and $\mathrm{C}_{3}$ grass (solid line: pstemp $\mathrm{min}_{\min }=-5^{\circ} \mathrm{C}$, optimum $10-35^{\circ} \mathrm{C}$, pstemp $p_{\max }=45^{\circ} \mathrm{C}$ ). Changed parameterisation (pstemp) for $P$. sylvestris $\left(\mathrm{pstemp}_{\min }=-10^{\circ} \mathrm{C}\right.$, optimum $15-25^{\circ} \mathrm{C}$, $\mathrm{pstemp}_{\max }=$ $\left.37^{\circ} \mathrm{C}\right)$.

(i.e. the upper plateau in Fig. 1) represents an effective temperature response of many enzyme- and transport-related processes. Within this optimum range, $t_{\text {scalar }}$ equals unity (i.e. $t_{\text {scalar }}$ is equal to 1$)$ and creates a slight rise in maximum carboxylation capacity $\left(V_{\mathrm{m}}\right)$, but reduces photosynthesis with increasing temperature. Outside this optimum range, both light-limited photosynthesis and $V_{\mathrm{m}}$ are reduced. Temperatures outside the sstemp $_{\min }$, pstemp $_{\max }$ range result in zero photosynthesis. Thus, apart from the abovementioned processes that follow enzyme kinetics, and are thus temperature dependent, $t_{\text {scalar }}$ imposes an additional temperature stress on photosynthesis calculations.

\subsubsection{Photosynthesis under water stress}

Plants experience water stress when water supply $(S)$ is smaller than the demand $(D)$. Supply is proportional to the available soil moisture in the rooting zone (wr) and the maximum possible transpiration rate under well-watered conditions $\left(E_{\max } ; 5 \mathrm{~mm} \mathrm{day}^{-1}\right.$ following Haxeltine and Prentice, 1996b):

$S=E_{\max } \cdot \mathrm{wr}$.

The demand is simulated with an empirically calibrated hyperbolic function of non-water stressed canopy conductance and the equilibrium transpiration (Huntingford and Monteith, 1998; Gerten et al., 2004). If the water supply is lower than the demand, canopy conductance is reduced until evapotranspiration (transpiration and evaporation from the canopy and the soil) equals the demand. This limits $\mathrm{CO}_{2}$ diffusion into the leaves, expressed in a reduction of the ratio of internal to atmospheric $\mathrm{CO}_{2}$ concentration, $c_{\mathrm{i}} / c_{\mathrm{a}}$. A lower $c_{\mathrm{i}} / c_{\mathrm{a}}$ ratio leads to a reduction of photosynthesis. 
Table 1. Parameter values for LPJ-GUESS. Values for this study are similar to Hickler et al. (2012), Table S1.1, except for values in bold font. $T_{\mathrm{c}, \text { max }}$ est represents maximum coldest-month temperature for establishment; drought ${ }_{\text {tol }}$ represents drought tolerance level of a species ( 0 is very tolerant, 1 is not at all tolerant); root $_{\text {distr[11] }}$ is fraction of roots in first soil layer (the remainder being allocated to second soil layer); sla is specific leaf area.

\begin{tabular}{llllll}
\hline Species/PFT & Growth form & $T_{\mathrm{c}, \text { max_est }}\left({ }^{\circ} \mathrm{C}\right)$ & drought $_{\text {tol }}{ }^{\mathrm{a}}(-)$ & $\operatorname{root}_{\mathrm{distr}[11]}(-)$ & sla $\left._{\left(\mathrm{m}^{2}\right.} \mathrm{kg} \mathrm{C}^{-1}\right)$ \\
\hline Pinus sylvestris & tree & limitless & 0.25 & 0.6 & $\mathbf{9 . 3}^{\mathrm{b}}$ \\
$\mathrm{C}_{3}$ herbaceous & herbaceous & limitless & 0.01 & 0.9 & 32.4 \\
\hline
\end{tabular}

a Similar to fAWC in Hickler et al. (2012), called drought tolerance here. Not always used by model, only when using species-specific water uptake from the soil (model setup S2, wr_speciesspecific).

b Value based on site measurements by Wilma Jans et al. (1997, unpublished data, available at http://www.climatexchange.nl/sites/loobos/) and Katrin Fleischer (2013, unpublished data).

\subsubsection{Plant water uptake parameterisations}

The soil hydrology is represented by a simple bucket model with two layers. The upper layer $\left(l_{1}\right)$ is $50 \mathrm{~cm}$ deep, and the lowest layer $\left(l_{2}\right)$ is $100 \mathrm{~cm}$ deep. Available soil moisture, wr, is the ratio between current soil water content and plant-available water capacity. The latter is dependent on soil type and texture (Sitch et al., 2003). The model offers the following three methods to calculate available soil moisture in the rooting zone (Supplement, Fig. S1). Method 1: $\mathrm{wr}$ is independent of soil water content until wilting point (wr_rootdist). This is the current standard used in most studies with LPJ-GUESS (T. Hickler, personal communication, 2013). Method 2: wr is influenced by a species-specific drought tolerance value (Table 1). In response to declining soil water, drought-tolerant species reduce transpiration less than drought-sensitive species and therefore have greater relative uptake rates (wr_speciesspecific; see Schurgers et al. (2009) for an application of LPJ-GUESS using this formulation). Method 3: wr declines linearly as a function of soil water content (wr_wcont, which is used in most studies with LPJ-DGVM, description in Haxeltine and Prentice, 1996b). A more detailed description of each method with equations is provided in the Supplement.

\subsection{Modelling setups}

\subsubsection{Default modelling setup}

As a driver, we used the site-specific meteorological data set of daily averages from 1997 to 2009, and this data set was repeated consecutively during the model run. To simulate the establishment of a Scots pine forest on a bare sand soil, we ran the model for 105 years (as a spin-up period), so that the simulated forest would have a stand age and soil carbon pools comparable to our study site. Only Pinus sylvestris and herbaceous vegetation with $\mathrm{C}_{3}$ photosynthesis (to represent the understory) were allowed to establish on a patch. Since Prunus serotina encroachment is relative recent and actively suppressed, we did not include this species in the model. Furthermore, the site has not been disturbed by fire since its establishment so we also did not include fire disturbance in the model. Finally, we used the averaged results of 100 replicate patches to account for any stochastic effects on vegetation establishment. All PFT/species-specific parameters for this study were taken from Hickler et al. (2012), except for two parameters (Table 1, bold values). Maximum coldest month temperature for PFT/species establishment $\left(T_{\left.\mathrm{c}, \text { max }_{\text {_est }}\right)}\right)$ was set to limitless for $P$. sylvestris, to ensure establishment of these planted trees at the temperate climate of Loobos. Specific leaf area (sla) for P. sylvestris was set to a site-specific value based on measurements (Table 1). For comparison of modelled carbon and water fluxes to EC data, modelled daily GPP, NEE, $R_{\text {eco }}$, plant transpiration, soil evaporation, and canopy interception are available. Modelled AET was calculated as the sum of plant transpiration plus evaporation from the soil and canopy. Water uptake was set to the default used in previous studies with this model: wr_rootdist.

\subsubsection{Alternative temperature response function}

Based on the results of the default model run (Sect. 3.1), we decided to decrease the lower temperature limit (pstemp $p_{\min }$, Eqs. 1 and 2) for Scots pine to allow photosynthesis on frost days. To compare our findings with existing data, and to determine a suitable lower temperature threshold for photosynthesis of mature Scots pine forests at temperate sites, we identified a limited number of previous studies relevant to the situation at Loobos. For example, James et al. (1994) measured photosynthesis and growth of Scots pine along a latitudinal gradient in Scotland (Creag Fhiaclach, Cairngorms National Park), and found that valley trees displayed higher photosynthesis rates in winter compared to those growing at higher latitudes. Teskey et al. (1994) report net photosynthesis in winter when there are no severe frosts and the soil is not frozen. Linder and Troeng (1980) report minimum atmospheric temperatures of $-7^{\circ} \mathrm{C}$ for net photosynthesis for $P$. sylvestris in southern Sweden, which is slightly higher than, but in a similar range as, that observed at our study site Loobos. Sevanto et al. (2006) show net uptake of carbon for many freezing days during the winter of 2002/03, and positive uptake in all previous 7 years except during January in southern Finland. At Brasschaat, a slightly younger (compared to Loo- 
bos) temperate mixed deciduous-coniferous forest in Belgium, net carbon uptake was observed only in the winter of 2001 (Carrara et al., 2003). At this site, however, not all trees are evergreen so winter LAI is lower compared to our study site.

In addition to the literature review, we analysed several types of available observational data in three different ways to determine a suitable lower temperature threshold. Analysis 1: we selected days from the EC data set between late November and late February, with average daily temperatures below $0^{\circ} \mathrm{C}(n=226)$. In order to see the effect of temperature on observed GPP and AET, days with low radiation were excluded; total net shortwave radiation received $>2 \mathrm{MJ} \mathrm{day}^{-1}$, which is an average of about $75 \mathrm{~W} \mathrm{~m}^{-2}$ for a winter day with $6 \mathrm{~h}$ of daylight. For days that met these criteria $(n=175)$, modelled and observed data were binned to temperature classes of $2^{\circ}$ ranging from $<=-10$ to $0^{\circ} \mathrm{C}$; Analysis 2: from a different study (Abreu, 2012), we included a fitted temperature response curve for maximum GPP (indicated as $\mathrm{GPP}_{1000}$ ). Abreu calculated $\mathrm{GPP}_{1000}$ following Jacobs et al. (2007), using half-hourly EC data between 1997 and 2011. Due to the large number of data points needed to calculate $\mathrm{GPP}_{1000}$, these results are only available for $5^{\circ}$ temperature bins between -5 and $35^{\circ} \mathrm{C}$; Analysis 3 : a 2-day measurement campaign with a portable ADC LCpro (ADC BioScientific, Hoddesdon, UK) was carried out at the study site in 2012 to measure leaf photosynthesis on days with temperatures below $0{ }^{\circ} \mathrm{C}$ (description and results in Supplement).

Based on the outcome of the literature review and observational data analysis, this model experiment uses a lower threshold for $P$. sylvestris photosynthesis ( pstemp $_{\min }$ ) of $-10^{\circ} \mathrm{C}$. Other than this lower threshold, this model setup does not differ from the default model setup.

\subsubsection{Alternative plant water uptake parameterisations}

In this setup, PFT/species-specific parameter values remained unchanged compared to the default setup, but we ran the model for all three available water uptake parameterisations (Sect. 2.2.4): (1) the default run (S1), using the standard "wr_rootdist" uptake, (2) a species-specific water uptake run (S2), and (3) a linear uptake run (S3). Figure S1 shows the different water uptake response curves for $P$. sylvestris and $\mathrm{C}_{3}$ grasses. Response curves differ between species as a result of PFT/species-specific root distributions ( root $_{\text {distr }}$, Table 1): $C_{3}$ grass has $90 \%$ of its roots prescribed in the upper soil layer $(0-50 \mathrm{~cm})$, and $10 \%$ in the lowest layer $(50$ $150 \mathrm{~cm}$ ), while for P. sylvestris this is 60 and $40 \%$, respectively. In the case of species-specific water uptake, the response curves also differ because grass and $P$. sylvestris have different assumed drought tolerance (drought $t_{\text {tol }}$, Table 1). Species-specific water uptake is represented with response curves $\mathrm{S} 2 \mathrm{a}$ and $\mathrm{b}$, with $\mathrm{C}_{3}$ grass having larger relative uptake rates than $P$. sylvestris under declining soil water content.
Linear decline of supply with decreasing soil water results in similar uptake rates for both $P$. sylvestris and $\mathrm{C}_{3}$ grasses, since modelled water uptake is independent of root distribution in this parameterisation (Fig. S1, response curve S3).

As a control, we include one additional model run (S4) using the standard water uptake method (wr_rootdist), but eliminated plant water stress by fixing wr to 1.0 so that supply is always equal to $E_{\max }$ (Eq. 4). Model results of setups S1-S4 were investigated in more detail for the summer period to determine the effect of a heatwave and corresponding drought on the observed and modelled carbon and water fluxes.

\subsection{Statistical tests}

To test how well the model predicts the observed values of GPP and AET, we applied a linear regression through the origin and used Pearson correlation tests. If the slope of the linear regression were equal to unity, our model would match the observed data with no systematic bias. Statistically significant differences from 1.0 in the regression slope were determined by a two-sided $t$ test at a threshold of $P=0.05$. The root mean square error (RMSE) between model and data was calculated as a measure of prediction accuracy, i.e. "goodness of fit". Additionally, a two-sided paired Wilcoxon ranking test was performed to determine if observed and modelled samples follow similar distributions. Only when $P$ values of this test are larger than 0.05 do we accept that the model produces a data distribution that is similar to the data distribution of the observations.

\section{Results}

\subsection{Default modelling setup}

The general site characteristics of Loobos are well represented by the default modelling setup (S1, Table 2): modelled LAI for Scots pine is 1.5, declining to 1.4 between 1997 and 2009. This LAI is just below the observed site average of 1.62 between 1997 and 2009 (minimum 1.44 in 2007, maximum 1.78 in 2009). Modelled LAI for $\mathrm{C}_{3}$ grasses is higher than observed (2.4 and 1.0 respectively), but few measurements of understory grass LAI were available for validation and none for mosses. Modelled aboveground biomass estimates are close to available observations.

Figure 2 shows the interannual and monthly variability in GPP and AET. Table 3 summarises the goodness-of-fit values for GPP and AET. The model shows good correlations on daily and monthly timescales (Fig. 2c and d). Monthly correlations are significant ( 0.92 for GPP, and 0.87 for AET), indicating that the model is accurately capturing the seasonal pattern of both fluxes. This is also visible in Fig. 3a and b. In contrast, we find poor correlations on the annual timescale: annual totals for GPP and AET are of the same order of magnitude as observed values, but the observed $\mathrm{IAV}_{\mathrm{cw}}$ is not captured well by the model for water or for carbon (Fig. 2a and 
Table 2. Modelled and observed site characteristics of Loobos. All modelled values for biomass are calculated for the period 19972009 , and multiplied by a factor 0.82 to exclude root biomass (taken from Jackson et al. (1996) as a topical value for conifer forests).

\begin{tabular}{llll}
\hline & \multirow{2}{*}{$\begin{array}{l}\text { Aboveground } \\
\text { biomass }\left(\mathrm{kg} \mathrm{C} \mathrm{m}^{-2}\right)\end{array}$} & Pinus sylvestris & $\mathrm{C}_{3}$ grass \\
\cline { 3 - 4 } & & $1.62^{\mathrm{b}}$ & $1.0^{\mathrm{c}}$ \\
\hline Observed: & $4.98^{\mathrm{a}}$ & & \\
\hline Modelled: & & 1.5 & 2.4 \\
Default/S1 & $5.95 \pm 0.10$ & 1.7 & 1.9 \\
pstemp & $7.18 \pm 0.14$ & 1.1 & 3.6 \\
S2 & $4.55 \pm 0.11$ & 1.2 & 2.8 \\
S3 & $4.72 \pm 0.11$ & 1.8 & 2.6 \\
S4 & $7.64 \pm 0.19$ & & \\
\hline
\end{tabular}

a $9.23 \mathrm{~kg} \mathrm{~m}^{-2}$ standing biomass in 1997, annual growth increment of $0.124 \mathrm{~kg} \mathrm{~m}^{-2}$ (data source: http://www.climatexchange.nl/sites/loobos/). To convert to carbon mass a factor of 0.5 was used (e.g. see Sandström et al., 2007; Thomas and Martin, 2012), resulting in an estimated average aboveground biomass between 1997 and 2009 of $4.98 \mathrm{~kg} \mathrm{C} \mathrm{m}^{-2}$.

b Measured average tree LAI from 1997 to 2009 (unpublished data), minimum 1.44 (2007), maximum 1.78 (2009), standard deviation is 0.10. Dolman et al. (2002) report maximum LAI of 1.9 for $1997 .{ }^{c}$ Measurements between 1999 and $2002(n=52)$, standard deviation $0.4 \mathrm{~m}^{2} \mathrm{~m}^{-2}$ (unpublished data).

b). The modelled data distribution is similar to observations (Table 3, bold values), but correlation coefficients are low and not significant ( 0.22 and 0.20 for GPP and AET, respectively).

The monthly scatter plots (Fig. 2c and d) display systematic model biases during certain periods. Fluxes are underestimated in winter, overestimated in spring/early summer, and slightly underestimated in autumn (Fig. 2c and d). In summer (mainly in August and July), large deviations from the $1: 1$ line can be seen, which we directly relate to periods with high atmospheric temperatures and low precipitation. Figure 3 shows these deviations per month in more detail.

\subsection{Alternative temperature response function}

\subsubsection{Observed temperature response}

According to the EC data, the vegetation at Loobos is able to keep assimilating carbon even at temperatures below $0{ }^{\circ} \mathrm{C}$ (Fig. 4). In the fitted response curve of half-hourly EC fluxes, maximum GPP for the lowest temperature class $(-5$ to $0{ }^{\circ} \mathrm{C}$, Fig. $4 \mathrm{a}$ ) is $1.8 \mu \mathrm{mol} \mathrm{m}^{-2} \mathrm{~s}^{-1}$, which corresponds to $1.87 \mathrm{~g} \mathrm{C} \mathrm{m}^{-2} \mathrm{day}^{-1}$. Figure $4 \mathrm{~b}$ shows temperature-binned daily GPP on sunny days, and the response to temperatures below $-10^{\circ} \mathrm{C}$. The lower temperature limit in our observational data, i.e. where average GPP approaches 0 , is found when temperatures are below $-8^{\circ} \mathrm{C}$. Note that the number of data points, however, in temperature class -8 to $-10^{\circ} \mathrm{C}$ is relatively low $(n=2)$. To further check data for this particular temperature class, we included half-hourly EC data for two such days (Figs. S4 and S5). On these days, NEE becomes negative and strongly responds to radiation, especially
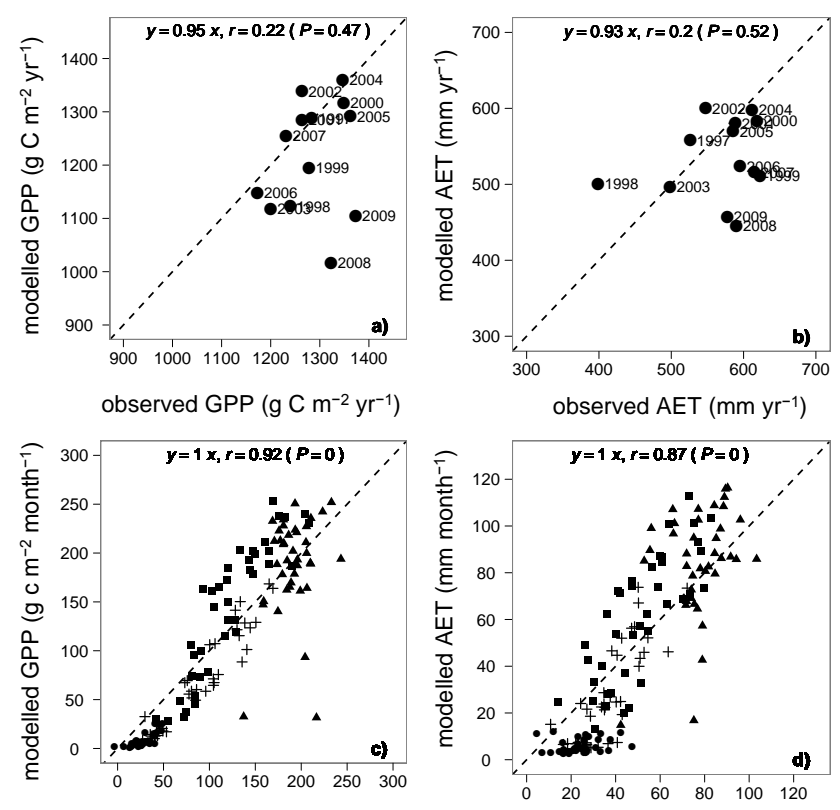

observed GPP ( $\mathrm{g} \mathrm{C} \mathrm{m}^{-2}$ month $^{-1}$ )

observed AET (mm month ${ }^{-1}$ )

Figure 2. Observed vs. modelled variability in GPP (a, c) and AET (b, d) for the default model scenario (S1) on annual (a, b) and monthly timescales $(\mathbf{c}, \mathbf{d})$. Dotted line is the $1: 1$ line. The equation shows linear regression through the origin, with correlation coefficients. Fluxes are hatched per season for sub-panels (c) and (d): black circles are for winter (December, January, February); black squares are for spring (March, April, May); black triangles are for summer (June, July, August); += autumn (September, October, November).

around noon. The average assimilation capacity for all the example dates in Figs. S4 and S5 correspond well with the upper quartile of daily observed GPP as shown in Fig. 4b. As can be expected, average observed GPP per day is slightly lower than the maximum capacity for a certain temperature class. The leaf level measurements (Fig. S6) also show active assimilation when atmospheric temperatures were below 0 , with $P$. sylvestris needles strongly responding to radiation. A linear regression through these data points gives a minimum of $-10.1^{\circ} \mathrm{C}$.

All three data sources indicate that carbon assimilation stops when temperatures fall below $-10^{\circ} \mathrm{C}$ (Fig. 4b), and when a prolonged period of extremely cold temperatures is observed. The latter was the case in early January 1997, even on days with high radiation and temperatures between -6 and $-8^{\circ} \mathrm{C}$ (Fig. $4 \mathrm{~b}$, first and second quartile).

\subsubsection{Modelled temperature response}

Based on the outcome of the literature review and observational data analysis, this model setup used a lower threshold for $P$. sylvestris photosynthesis $\left(\mathrm{pstemp}_{\min }\right)$ of $-10^{\circ} \mathrm{C}$. The effect of changing the temperature response in LPJ-GUESS on the seasonal trend of GPP and AET is shown in Figs. 3, 
Table 3. Goodness-of-fit values for model scenarios S1-S4 and changed temperature response function, "pstemp". Correlation coefficient ( $r$ ) and RMSE for daily, monthly and annual data. Bold values represent data distributions that are identical using the Wilcoxon ranking test.

\begin{tabular}{|c|c|c|c|c|c|c|c|c|c|c|c|c|}
\hline \multirow[b]{3}{*}{ Run } & \multicolumn{6}{|c|}{ GPP } & \multicolumn{6}{|c|}{ AET } \\
\hline & \multicolumn{2}{|c|}{ annual } & \multicolumn{2}{|c|}{ monthly } & \multicolumn{2}{|c|}{ daily } & \multicolumn{2}{|c|}{ annual } & \multicolumn{2}{|c|}{ monthly } & \multicolumn{2}{|c|}{ daily } \\
\hline & $r$ & RMSE & $r$ & RMSE & $r$ & RMSE & $r$ & RMSE & $r$ & RMSE & $r$ & RMSE \\
\hline Default/S1 & 0.22 & 125.9 & $0.92^{*}$ & 35.7 & $0.79^{*}$ & 2.20 & 0.20 & 77.7 & $0.87^{*}$ & 19.7 & $0.62^{*}$ & 1.27 \\
\hline pstemp & 0.16 & 109.3 & $0.90^{*}$ & 36.3 & $0.78^{*}$ & 2.15 & 0.21 & 73.4 & $0.87^{*}$ & 19.6 & 0.62 & 1.25 \\
\hline S2 & 0.32 & 128.6 & $0.92^{*}$ & 32.6 & $0.81^{*}$ & 1.93 & 0.19 & 90.8 & $0.87^{*}$ & 17.2 & $0.65^{*}$ & 1.03 \\
\hline S3 & 0.27 & 198.9 & $0.92^{*}$ & 31.4 & $0.81^{*}$ & 1.78 & 0.13 & 141.9 & $0.86^{*}$ & 17.3 & $0.65^{*}$ & 0.94 \\
\hline S4 & 0.24 & 231.3 & $0.94^{*}$ & 51.9 & $0.85^{*}$ & 2.45 & 0.31 & 168.3 & $0.88^{*}$ & 36.2 & $0.68^{*}$ & 1.67 \\
\hline
\end{tabular}

* Significance tests for Pearson correlation: $P$ value $<0.05$.

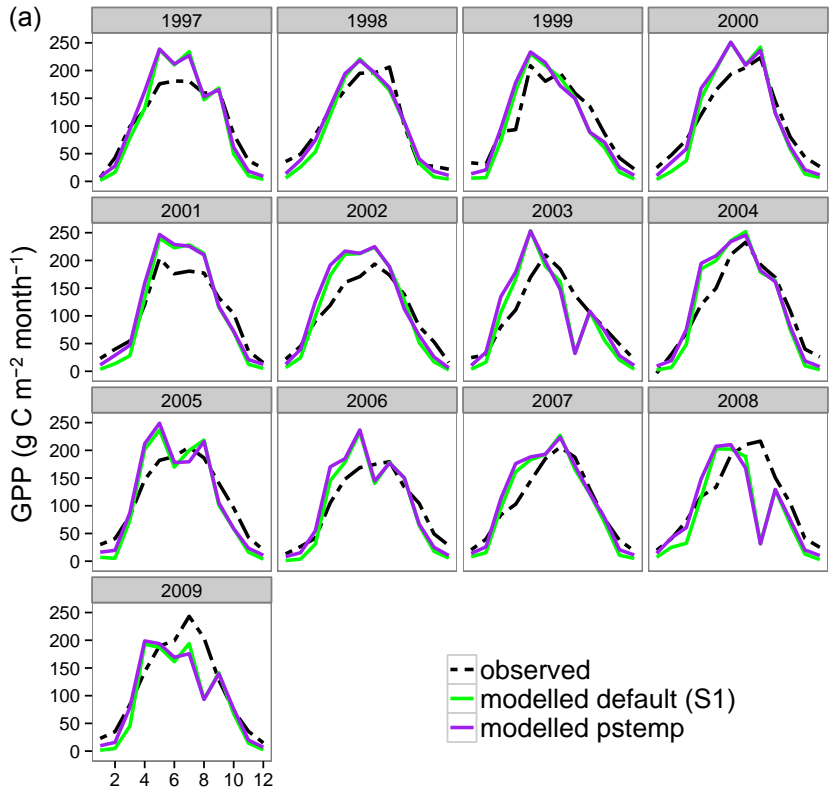

Month

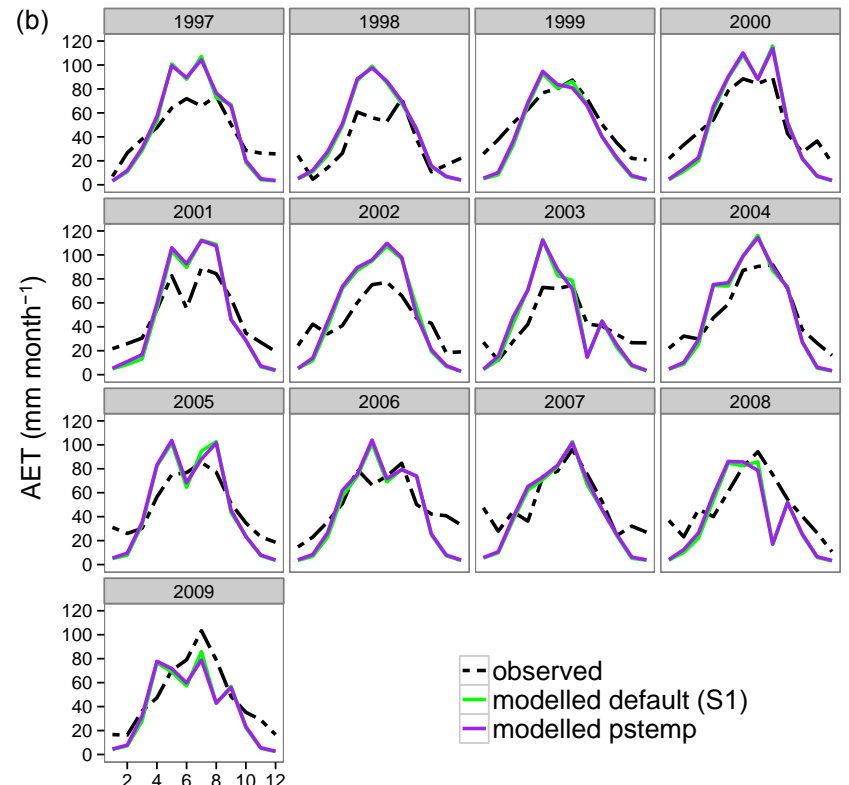

Month

Figure 3. Observed (black dotted line) and modelled values for default (S1, green line) and changed temperature response (pstemp, purple line) runs. (a) Monthly values for GPP $\left(\mathrm{g} \mathrm{C} \mathrm{m}^{-2} \mathrm{month}^{-1}\right)$. (b) Monthly values for AET (mm month $\left.{ }^{-1}\right)$.

5, and 6. Changing the lower boundary for photosynthesis for P. sylvestris to $-10^{\circ} \mathrm{C}$ (Fig. 1) results in higher winter estimates for GPP (Figs. 3a and 5a) and, to a lesser extent, for AET (Figs. 3b and 5b). The latter can be expected since interception and soil evaporation do not change and there is only a slight increase in plant transpiration. When selecting days with high radiation only (Fig. 5), simulations with changed temperature response follow the distribution of daily observed GPP more closely. For the entire simulation, the overall error (RMSE, Table 3) reduces for both AET and GPP, with the exception of GPP at monthly timescales. Correlations ( $r$, Table 3$)$ do not increase for GPP, and are similar for AET over the entire simulation period. However, the Wilcoxon ranking test shows that for GPP the modelled data distribution is now matching the observed data distribution at monthly timescales more closely $(P<0.05)$. In addition, when only winter month data are included (Fig. 6), the slope of the regression substantially improves for GPP from 0.32 to 0.58 , while keeping a similar correlation coefficient $(0.80 \mathrm{vs}$. 0.78 ). This indicates a better match between modelled and observed results. By changing the temperature response, the simulation of $\mathrm{IAV}_{\mathrm{cw}}$ does not improve for the carbon fluxes, and only marginally for the water fluxes (Table 3 ).

\subsection{Alternative plant water uptake parameterisations}

Figure 7 shows modelled carbon and water fluxes on a monthly timescale for the three different water uptake parameterisations (S1-S3) and the control model setup without soil moisture stress (S4). All three uptake parameterisations appear to be equally strong in simulating the seasonal 

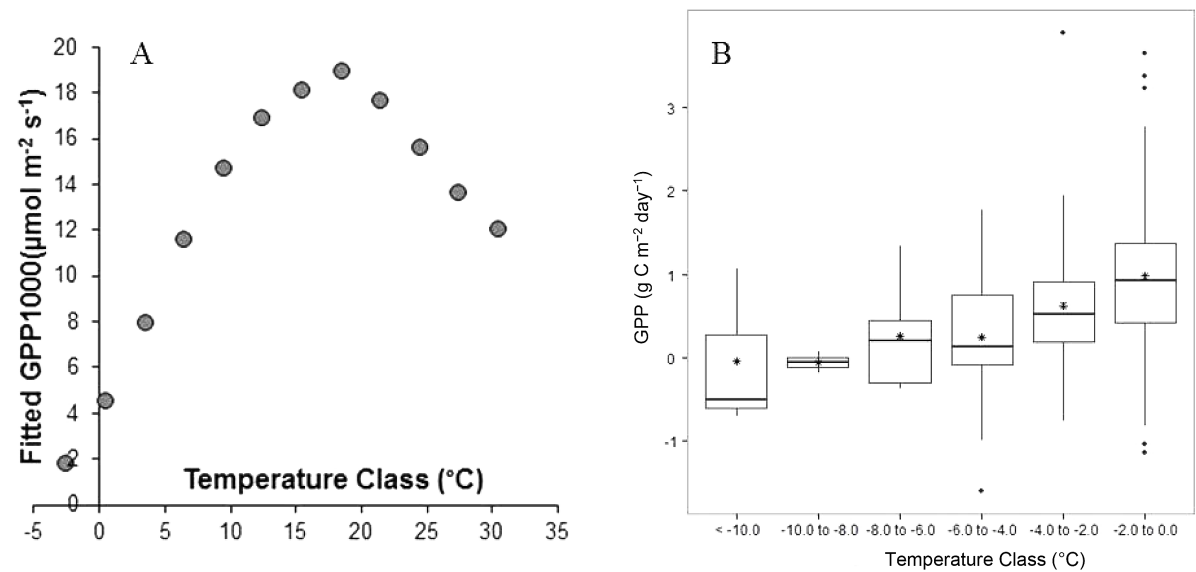

Figure 4. Observed temperature responses at Loobos. (a) Courtesy of P. Abreu: fitted GPP at a solar light intensity of $1000 \mathrm{~W} \mathrm{~m}^{-2}(\mathrm{GPP} 1000$, $\mu \mathrm{mol} \mathrm{m}{ }^{-2} \mathrm{~s}^{-1}$ ) based on half-hourly EC measurements (1997-2011) following Jacobs et al. (2007); (b) daily GPP (g C m ${ }^{-2} \mathrm{day}^{-1}$ ) observed at Loobos calculated from site EC measurements, for days with average daily temperatures $<0{ }^{\circ} \mathrm{C}$ and total net radiation received $>2 \mathrm{MJ}$ day $^{-1}(n=175)$.
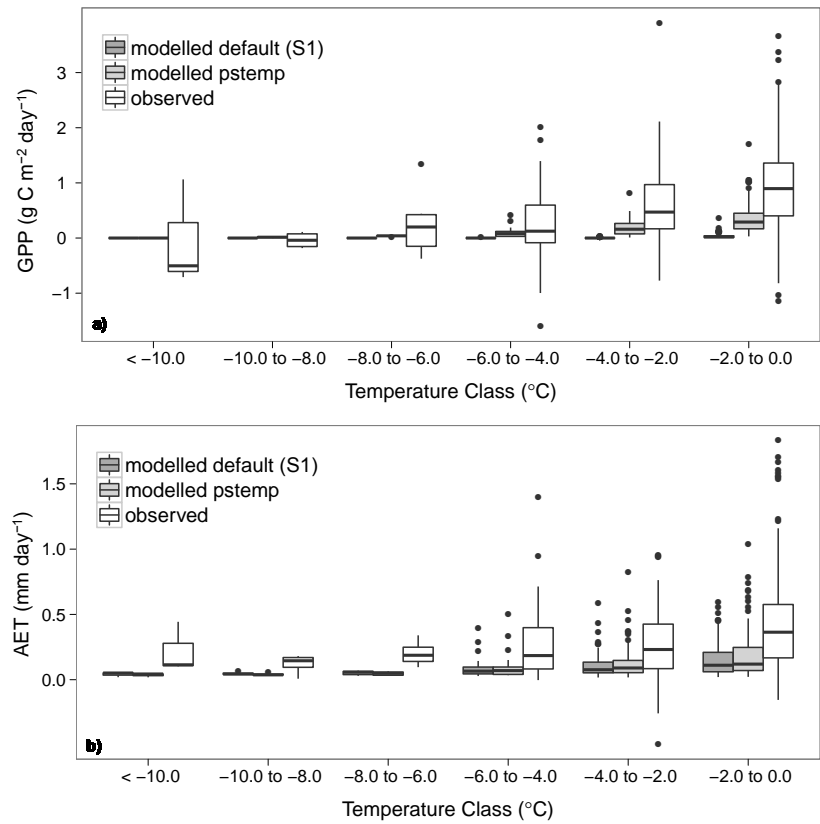

Figure 5. Effect of change in temperature scalar, $t_{\text {scalar, on }}$ modelled estimates of (a) GPP $\left(\mathrm{g} \mathrm{C} \mathrm{m}^{-2} \mathrm{day}^{-1}\right)$ and (b) AET $\left(\mathrm{mm} \mathrm{day}^{-1}\right)$. pstemp $_{\min }$ for Pinus sylvestris is set to $-10^{\circ} \mathrm{C}$, other values remain unchanged. White: observed values; dark grey: modelled default (S1); light grey: changed $t_{\text {scalar }}$ function (pstemp). Results for days with net radiation $>2 \mathrm{MJ}$ day $^{-1}$.

trend with correlations of $0.92-0.94$ for GPP and $0.86-0.88$ for AET ( $r$, Table 3). During summer, the linear uptake response curve (S3) underestimates both AET and GPP more often than the species-specific (S2) and default uptake (S1) parameterisations. Eliminating water stress (model setup S4) results in overestimation of fluxes during summer, increased
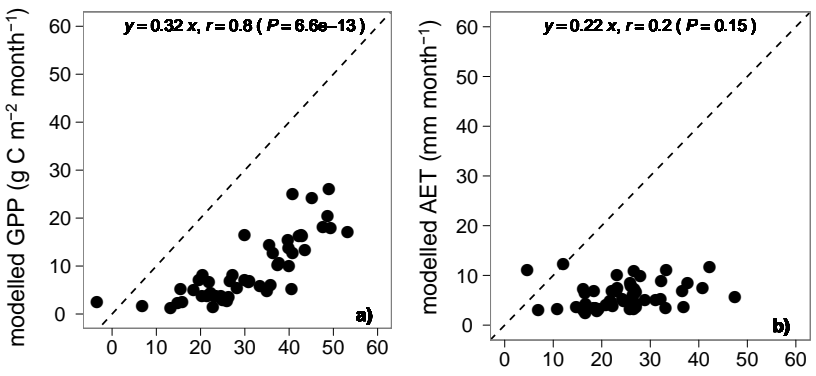

observed GPP ( $\mathrm{g} \mathrm{C} \mathrm{m}^{-2}$ month $\left.^{-1}\right)$

observed AET (mm month-1)

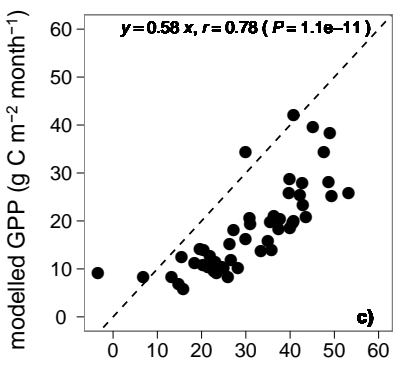

observed GPP ( $\mathrm{g} \mathrm{C} \mathrm{m}^{-2}$ month $\left.^{-1}\right)$

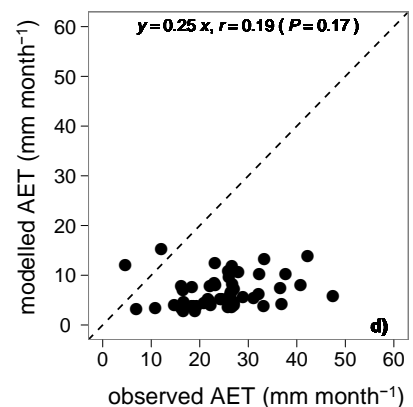

Figure 6. Variability during winter on monthly timescale for $(\mathbf{a}, \mathbf{b})$ GPP $\left(\mathrm{g} \mathrm{C} \mathrm{m}^{-2}\right.$ month $\left.^{-1}\right)$ and $(\mathbf{c}, \mathbf{d})$ AET $\left(\mathrm{mm} \mathrm{month}^{-1}\right)$, between default settings ( $\mathrm{S} 1$, a and $\mathbf{c}$ ) and changed $t_{\text {scalar }}$ (pstemp, b and d) during winter. All days in December, January, and February are included (i.e. no selection for radiation). All slopes significantly differed from 1.0 ( $P<0.05)$. RMSE values: (a) 22.7, (b) 20.4, (c) 14.7, and (d) 19.7 .

error, and lower RMSE. Moreover, with this setup both AET and GPP are overestimated in spring and summer for all years (Fig. 7a), indicating that water limitation does play an important role in Loobos. 


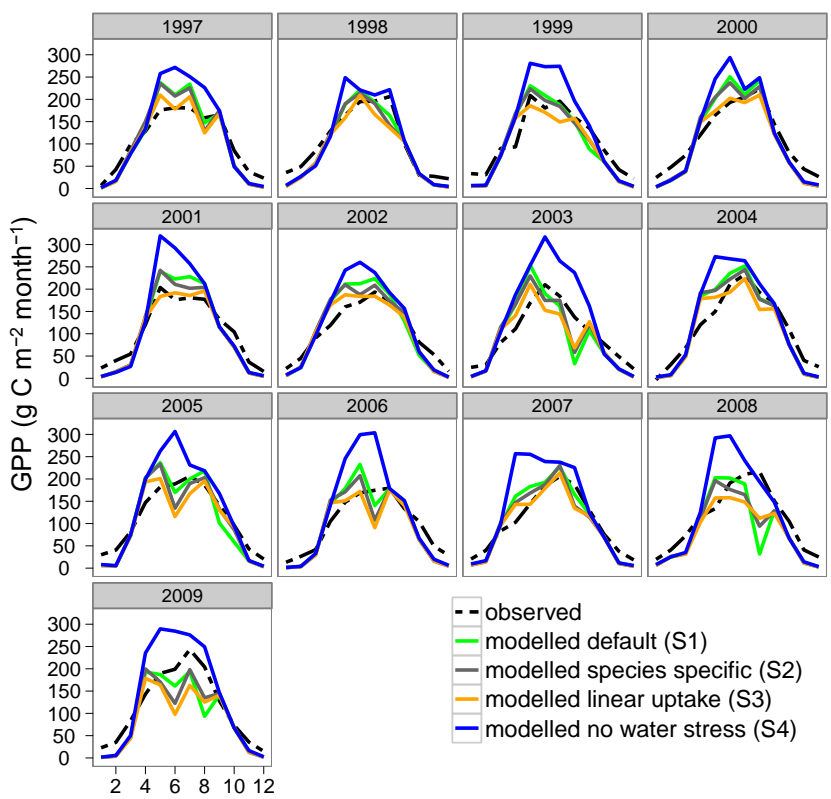

Month

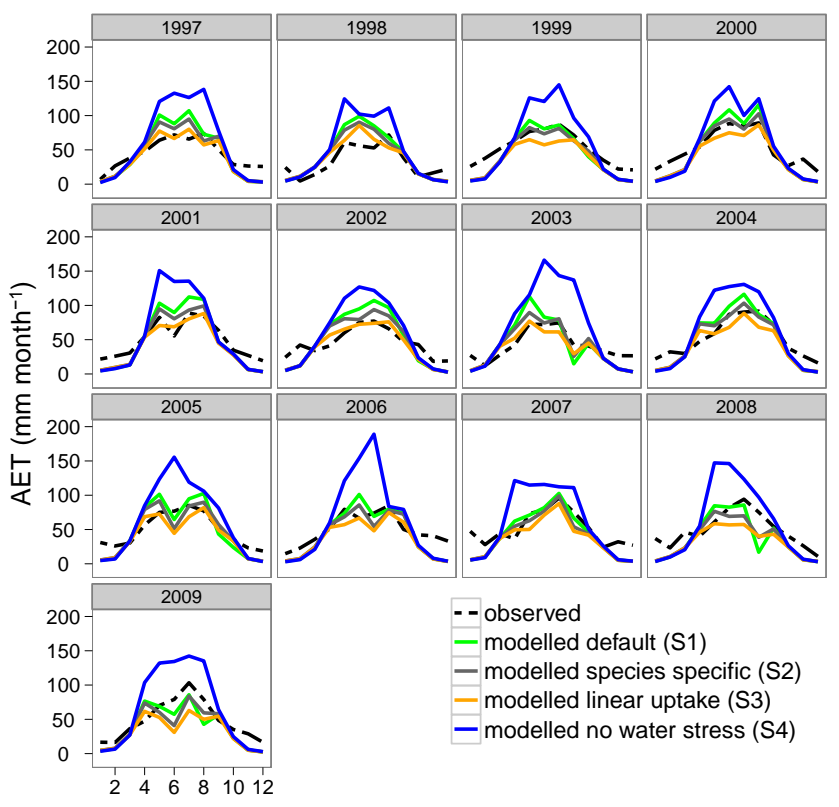

Month

Figure 7. Comparison of fluxes for (a) GPP $\left(\mathrm{g} \mathrm{C} \mathrm{m}^{-2} \mathrm{month}^{-1}\right)$ and (b) AET $\left(\mathrm{mm} \mathrm{month}^{-1}\right)$ using different water uptake functions. Dotted line: observed values. Solid lines: modelled values for scenarios S1-S4.

Given the model's very simple two-layer soil hydrology (Sect. 2.2.4) and the fact that our measured soil moisture data were averaged to correspond with the model's layer depths $\left(l_{1}\right.$ and $l_{2}$ ), seasonal soil moisture patterns are captured reasonably well between the different model setups when compared to observations (Fig. S3). Modelled soil moisture in the upper soil layer changes more rapidly than observations suggest, and modelled moisture recharge in winter increases to higher values than observed for some years. Soil moisture measurements, however, were not always available during winter and completely absent from autumn 2000 until summer 2002. Because plants take up water more conservatively in setup S3, modelled soil moisture is higher during the growing season for all years compared to the other two setups, and the bucket never completely empties as is often the case for the other two setups. Available sap flow data for P. sylvestris (1997, 1998, and 2009) show good correlations with modelled transpiration (Fig. 8, $r=0.68-0.74$ ). For setups S2 and S3, the range of modelled plant transpiration is lower than the observed plant transpiration (0-1.5 and $0-3 \mathrm{~mm}$ day $^{-1}$ respectively). For setup S1, the range of modelled plant transpiration matches that of the observations for 1997 and $1998\left(0-3 \mathrm{~mm} \mathrm{day}^{-1}\right)$. This relates directly to the shape of the response curve for each setup (Fig. S1), where $\mathrm{S} 2$ and S3 reduce the water supply, S, more strongly than S1 in response to declining soil water. Correlations for individual years are lowest for 1997, especially for setups S2 and S3, where modelled transpiration is reduced too strongly in response to declining modelled soil water between day 100 and 300 (Fig. S3).
On the annual timescale, species-specific uptake (S2) leads to the best explanation of interannual variability in GPP in terms of correlation coefficient (Table 3), while for AET there is a small decrease compared to the default setup. Using the model setup in which soil water is not a limiting factor (S4), the model also cannot accurately capture interannual variability in GPP and AET.

\section{Comparing water uptake parameterisations during a dry and wet summer}

The summers of 2003 and 2005 were very different, with the 2003 heatwave over Europe affecting both managed and natural vegetation systems but each ecosystem showing different responses to the extreme heat (e.g. see Granier et al., 2007; van der Werf et al., 2007; Teuling et al., 2010). The 2003 heatwave affected the Netherlands (KNMI, 2003) especially in August, which in combination with a prolonged period of low precipitation resulted in a drought. We compare the results of the extremely sunny, warm, and dry August 2003 to those of August 2005, which was a regular but very wet month. Observed soil moisture at Loobos declined considerably during the 2003 heatwave, and modelled soil water runs out earlier than observations suggest (Fig. 9, for 2003), with the exception of setup S3 and, to a lesser extent, for the lower soil layer of setup S2. For 2005, modelled soil moisture is often too low when using the default setup (S1), and water content of the upper layer changes more rapidly than observations suggest. 

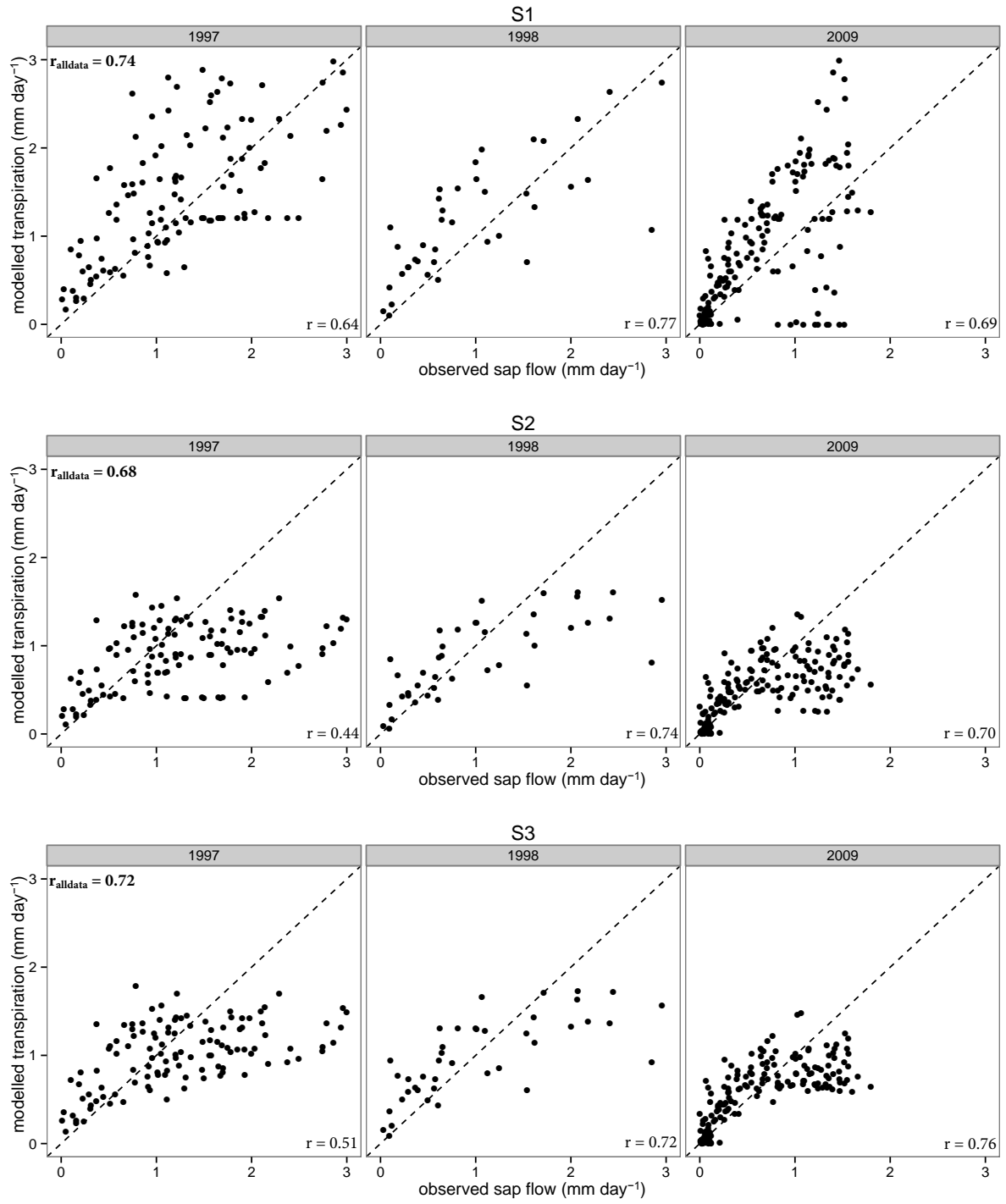

Figure 8. Modelled transpiration $\left(\mathrm{mm} \mathrm{day}^{-1}\right)$ for Pinus sylvestris, compared to observed sap flow (mm day ${ }^{-1}$ ). Pearson correlation coefficients significantly different from $0(P<0.01)$ for all separate years as well as all data points together $\left(r_{\text {alldata }}\right)$. Sap flow measurements for 1997 and 1998 acquired using tissue heat balance systems, and for 2009 using Granier thermal dissipation probes. S1 is default uptake, S2 is species-specific uptake, S3 is linear uptake.

When comparing daily carbon and water fluxes to observations (Fig. 10) during the wet period (2005), all uptake parameterisations perform well compared to observed data, with no striking differences between uptake parameterisations in simulating GPP and AET. During the 2003 heatwave and drought however, the parameterisations show different responses. During the first half of the heatwave period (indicated by the two vertical dotted black lines in Fig. 10), there is a gradual decline in observed daily GPP and AET at the site. Given the considerable drop in observed soil water during the heatwave (Fig. 9), reductions in observed GPP and AET look considerably more gradual (Fig. 10). This suggests the vegetation's possible access of water from deeper layers, or groundwater. The no-water stress control run (S4) clearly demonstrates there is some water stress at Loobos (both observed GPP and AET are lower than the model predicts), but all parameterisations fail to simulate the correct response. The default and species-specific response curves (S1 and S2) allow PFTs and species to take up relatively more water at low soil water contents compared to the linear uptake parameterisation, thereby not restricting photosynthesis as long as water remains available for uptake. We can observe this effect during the heatwave period, where the linear uptake function (S3) least underestimates GPP and AET, because there is more water available for uptake due to conservative water use, and the effects on the modelled supply are less strong at lower soil water contents (Figs. S1 and S2). The real observed response of the Loobos vegetation, however, is not 

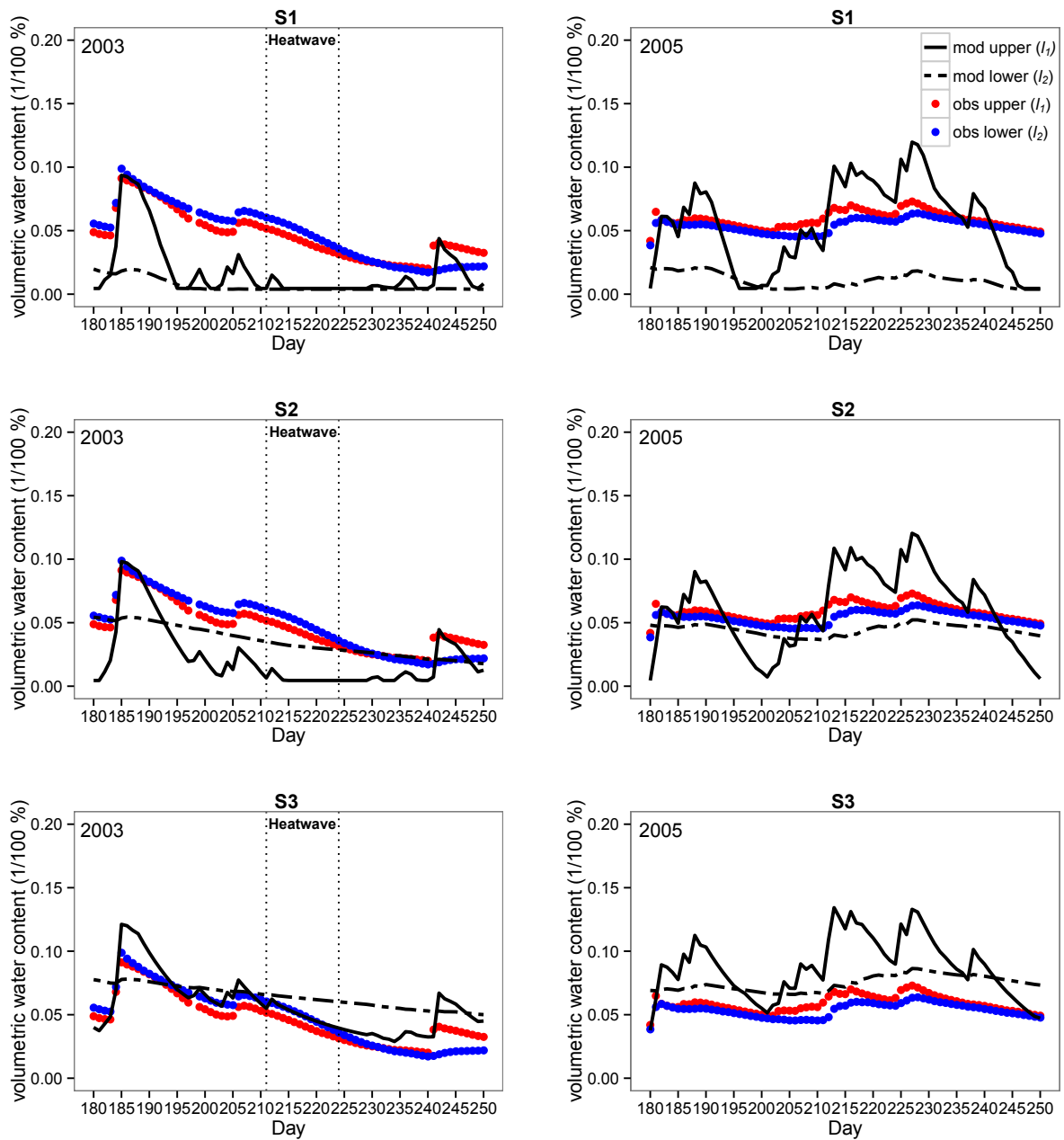

Figure 9. Daily modelled (mod, black lines) and observed (obs, red and blue) soil moisture (as volumetric water content, $1 / 100 \%$ ) for summer of 2003 and 2005. The two depths refer to the two soil layers in LPJ-GUESS: $l_{1}(0-50 \mathrm{~cm})$ and $l_{2}(50-150 \mathrm{~cm})$. For 2003 , the heatwave period is indicated between the black lines.

reproduced using either uptake parameterisation. The sensitivity of GPP and AET to declining soil moisture during the growing season is visible in Fig. S2 by plotting the residuals (modelled values minus observed values, so that an underestimation is depicted with a negative sign) against modelled available soil moisture $(\Theta)$. In general, the linear uptake parameterisation seems to underestimate both GPP and AET more at higher soil moisture values, so regarding the observations, this response curve imposes water stress on plants at this site too strongly.

A comparison of the three different plant water uptake response curves does not lead to identification of any setup that is clearly superior for simulating $\mathrm{IAV}_{\mathrm{cw}}$ compared to the others (Table 3). Species-specific uptake (S2) results in the smallest errors (RMSE, Table 3) on monthly and daily timescales, but on annual timescale the default uptake (S1) has the smallest error.

\section{Discussion}

\subsection{Default modelling setup}

The model reproduced the daily and monthly carbon and water fluxes equally well as shown in previous studies with LPJGUESS (Sitch et al., 2003; Gerten et al., 2004; Morales et al., 2005; Zaehle et al., 2005; Hickler et al., 2006). Fatichi and Ivanov (2014), using a different process-based vegetation model, similarly found very high correlations on daily timescales and low correlations on annual timescales for GPP and evapotranspiration. However, good correlations on shorter timescales can be expected, given the strong diurnal and seasonal cycles to climatic drivers (mainly radiation and temperature). While the model produces reasonable flux estimates at daily and monthly timescales, the small deviations on these timescales lead to poor estimates of $\mathrm{IAV}_{\mathrm{cw}}$ and longer timescales, which Keenan et al. (2012) demonstrated for a wide range of terrestrial biosphere models. 

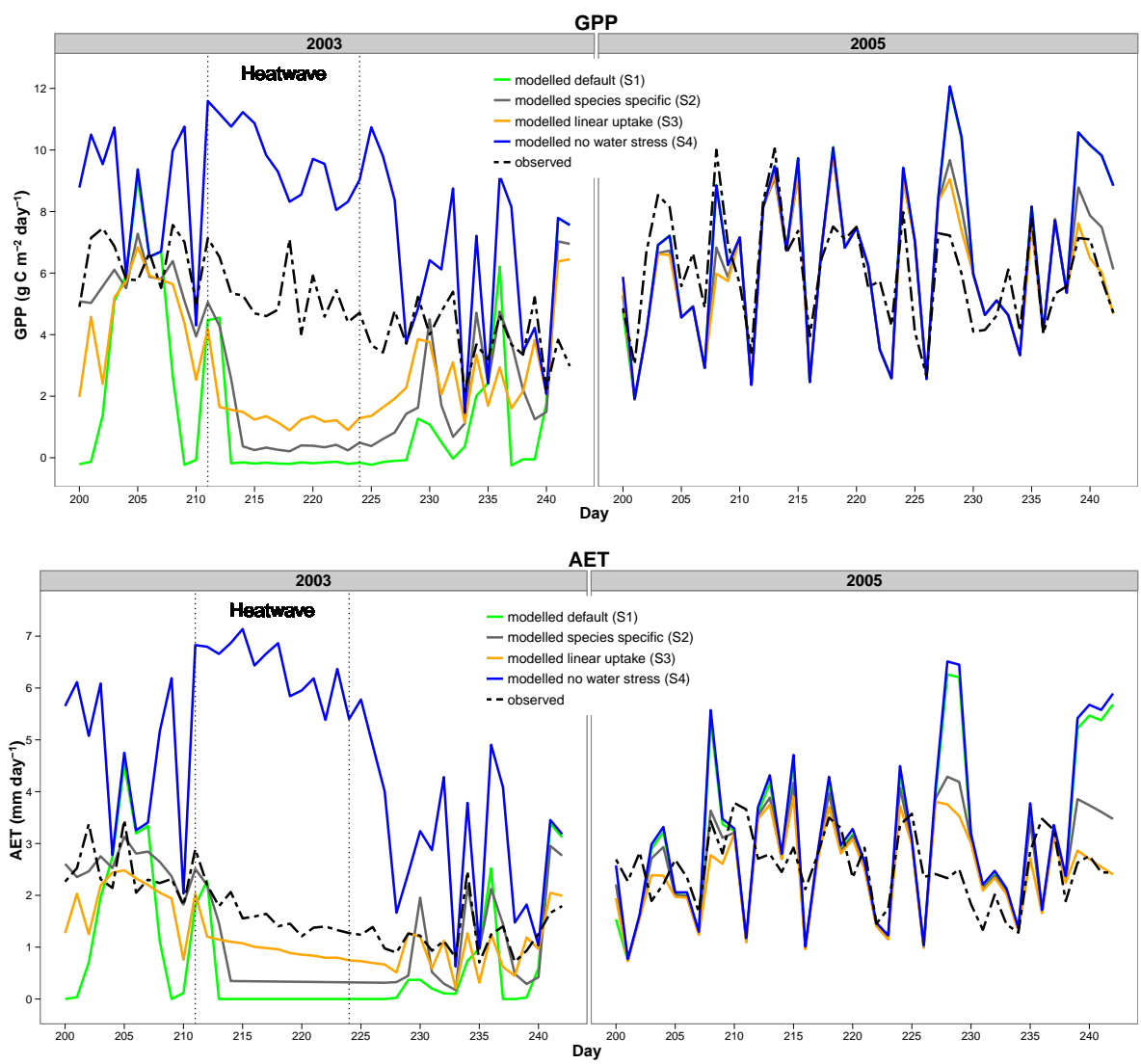

Figure 10. Daily observed and modelled fluxes for (a) GPP $\left(\mathrm{g} \mathrm{C} \mathrm{day}^{-1}\right)$ and (b) AET (mm day $\left.{ }^{-1}\right)$ for July and August in two different climate years. In summer 2003, a heatwave and corresponding drought occurred in Europe (e.g. see Teuling et al., 2010). Based on longterm averages of the Dutch Royal Meteorological Institute (KNMI), higher temperatures, more sunshine hours, and much less precipitation occurred during this summer, and an official heatwave took place in the Netherlands during August (KNMI, 2003). The KNMI defines a heatwave as a period of at least 5 consecutive days in which the maximum temperature exceeds $25^{\circ} \mathrm{C}$, provided that on at least 3 days in this period the maximum temperature exceeds $30^{\circ} \mathrm{C}$. Based on these criteria, the heatwave duration was from $31 \mathrm{July}$ to 13 August and is marked in the graph by two dotted black vertical lines. The summer of 2005 had average temperatures and sunshine but was much wetter, and August was a month with particularly high precipitation compared to long-term averages (KNMI, 2005).

At some sites where needleleaf evergreen vegetation is the dominant vegetation type, year-to-year variation in fluxes can be explained by climatic and environmental drivers (e.g. disturbances) only. For example, Sierra et al. (2009) applied a process-based stand vegetation model which showed that some forests are mostly affected by short-term dynamics such as disturbances, and others are more influenced by climatic controls. Duursma et al. (2009) performed a modeldata comparison using a calibrated empirical photosynthesis model, and found good fits for GPP on daily to seasonal timescales for several European FLUXNET sites and, similar to this study, comparably poor fits on the annual timescale. They attributed part of this mismatch to uncertainty in the EC data, variations in LAI, and reductions in GPP as a result of soil drought. Purely observational studies at temperate coniferous forests in Brasschaat (Carrara et al., 2003, 2004) and Vielsalm (Aubinet et al., 2002) showed that climatic and ecological drivers (such as changes in LAI, phenology shifts) ex- plain the majority of interannual variability in observed carbon and water fluxes. Our results, as well as studies by Jacobs et al. (2009), Kruijt et al. (2009) and Luyssaert et al. (2007), suggest that, in addition to direct climatic and environmental factors, ecological drivers also operate at the Loobos site.

\subsection{Uncertainties in the observational data set}

For this study, the mismatch between simulated and observed fluxes both at the monthly and at the annual timescale can only be partly attributed to uncertainties in the flux data. The magnitude of the error for this data set is estimated by Elbers et al. (2011) as $8 \%$ of annual NEE, which is a quarter of the standard deviation of annual NEE, and is small compared to other flux sites (Elbers et al., 2011, data from 1997 to 2010). Because GPP is estimated from NEE and night-time respiration, the errors in annual NEE, especially the notorious errors in night-time NEE due to low turbulence, propagate into GPP 
estimates. During winter, when relatively more data are gapfilled, this uncertainty in the data can contribute to a higher deviation between the modelled and observed results in this study.

\subsection{Alternative temperature response function}

\subsubsection{Observed temperature response at Loobos and similar sites}

We presented strong evidence that Pinus sylvestris continues to assimilate during winter in temperate climates, and even acts as a carbon sink during frost periods rather than as a source, as most DGVMs currently suggest (Morales et al., 2005). Falge et al. (2002) even suggest, based on their analysis of FLUXNET data, that temperate and boreal conifers should be seen as two separate classes. The observations at Loobos support this suggestion, as Pinus sylvestris clearly continues to assimilate in winter during all years, even when daily average temperatures drop below $0{ }^{\circ} \mathrm{C}$. These pine trees grow in a temperate climate, and therefore experience relatively milder winters compared to the same species at boreal sites. Plants are known to acclimatise to their growing conditions, so differences in the seasonal carbon gain within species reflect to a large extent the light and temperature environment in which they exist (Teskey et al., 1994). Plants native to a colder climate exhibit higher photosynthetic rates under colder temperatures, but, at higher latitudes, Pinus sylvestris is also known to display winter photo-inhibition as a result of lower winter temperatures (Berry and Bjorkman, 1980). This winter inhibition of photosynthetic capacity is thought to be a protective mechanism against damaging combinations of low atmospheric temperatures and exposure to high irradiances that can be enhanced by snow cover. If, however, winters are warm enough, photosynthesis in evergreen forest stands can continue if enough soil water is available to meet the transpirational demand (Sevanto et al., 2006, and references therein). How long it takes for the photosynthetic capacity to diminish during extended cold periods - and possibly recover when temperatures rise again (e.g. see Suni et al., 2003a, b; Kramer et al., 2008; Kramer and Hänninen, 2009) - is not known for this site and will be investigated in a winter measurement campaign of leaf photosynthesis over the next few years.

\subsubsection{Modelled temperature response}

The modelled changed temperature response function had a smaller effect on simulated AET than on simulated GPP (Fig. 5). Simulated AET is calculated as the sum of plant transpiration, soil evaporation, and canopy evaporation. Underestimation of canopy evaporation (interception loss) in relation to precipitation intensity in winter can play a role here. In general, measured AET fluxes during winter are high for this type of forest. At Loobos, measured AET peak values during winter are mainly the result of high interception evaporation (Elbers et al., 2010). Modelled LAI was slightly lower than observed (Table 2), which results in a lower precipitation storage capacity for the vegetation than in reality. Additionally, as the model does not explicitly handle shower intensity, and prolonged periods of low precipitation intensity occur often at the site during winter, the model underestimates interception evaporation. This underestimation of canopy interception likely contributes to underestimations of AET on the longer timescales as well.

Even when Pinus sylvestris is allowed to continue assimilating at lower temperatures, the difference between modelled and observed fluxes improves but is not completely resolved. The shape of the temperature response curve for $\mathrm{Pi}$ nus sylvestris (Fig. 1) is modelled as a steep increase from the minimum temperature ( pstemp $_{\min }$ ) to the optimum temperature (pstemplow), which, to our knowledge, is not supported by literature but purely empirical. For this study, we identified a lack of data and literature to verify the exact shape of this response curve and instead calculated the minimum temperature threshold from the available data. Smith and Dukes (2013) reviewed the latest available methods to incorporate photosynthesis temperature acclimation into globalscale models, and suggest that instead of just looking at temperature optima, shifts in the slope/intercept of the initial instantaneous temperature response could be of equal or greater importance, especially at suboptimal temperatures, and that a combination of data collection and modelling studies, such as ours, is needed to improve our understanding and realistically simulate long-term responses of vegetation to temperature shifts.

The small impact of changing the temperature response function on simulating $\mathrm{IAV}_{\mathrm{cw}}$ is of course related to the fact that wintertime fluxes make up only a small part of the total annual flux (average observed annual GPP for this data set is $1284 \mathrm{~g} \mathrm{C} \mathrm{m}^{-2}$ ), usually less than $10 \%$. In contrast, the largest observed interannual difference in GPP for this period is almost twice as large at $200 \mathrm{~g} \mathrm{C} \mathrm{m}^{-2}$. Therefore, small improvements in the winter estimates will not translate directly into good estimates and high correlation coefficients on the annual timescale.

\subsection{Alternative plant water uptake parameterisations}

The use of three different soil water uptake parameterisations revealed that the model can satisfactorily simulate GPP and AET during wet summers such as that of 2005. The model performed well for the years when plant transpiration for Scots pine could be compared with sap flow observations (Fig. 8). However, none of the uptake parameterisations capture the observed response in terms of GPP and AET to a drought such as occurred in the summer of 2003 (Fig. 10). In addition, none of the three parameterisations consistently improved all results or improved simulated $\mathrm{IAV}_{\mathrm{cw}}$ at Loobos.

Previous studies have demonstrated that LPJ-GUESS is sensitive to limitations in soil moisture, firstly because the 
parameters controlling stomatal conductance are very sensitive to plant water stress (Zaehle et al., 2005) and secondly because the model does not account for plant ability to access water from deeper soil layers and aquifers in water-limiting situations (Hickler et al., 2006; Wramneby et al., 2008). The debate on how to improve modelling efforts in a mechanistic way, however, is still ongoing. For example, Hickler et al. (2006) included plant hydraulic architecture in the global model version of LPJ, thereby changing the calculation of plant water supply to a more mechanistic scheme. This improved global simulations of AET, but the updated model requires additional PFT/species-specific parameters that are often not available and the model still underestimates summer AET at one Mediterranean test site. Verbeeck et al. (2011) tried increasing soil depth and used locally varying root profiles to improve simulations of dryseason GPP for the tropics. Such an approach, however, does not lead to the desired mechanistic model improvements because it eliminates simulated water stress completely. Furthermore, high-quality data on effective rooting depth, soil volume, and deep soil water are rarely available, and deriving model parameters representing deep tap roots, sometimes growing through rock fissures or compacted soil layers, is difficult. These challenges are probably the reason why access to deep water is, to our knowledge, not captured in any DGVM. Nevertheless, we think that further efforts should be devoted to improving the current state of the art in this respect, because access to deep water is probably crucial in many ecosystems around the world.

The 2003 summer drought simulations at Loobos confirm the strong model sensitivity to drought: under dry soil moisture conditions the vegetation shows a much more gradual response in flux reduction compared to the model runs (Fig. 10). Observed soil moisture values are low and gradually decline during the heatwave (Fig. 9), suggesting that the vegetation can access water from deeper layers, or groundwater. Pinus sylvestris is known for its ability to create long tap roots, especially when growing on sandy soils, so that water uptake is also possible from sparsely rooted deep soil layers when water becomes limiting (Jarvis, 2011).

The shape of the water uptake response curves in the model clearly has an effect on the water uptake (Fig. S1). The exact shape of this curve, however, is both species and site specific, and remains poorly defined for global model studies that use broad PFT classifications. For P. sylvestris, Lagergren and Lindroth (2002) summarised uptake curves from several studies, and the reported shapes are very similar to the ones used in this study, most closely resembling wr_rootdist and wr_speciespecific. The reality probably lies in between the original linear formulation and wr_rootdist, because plants do not reduce transpiration immediately when soil water content declines: transpiration remains unaffected until the soil water potential reaches values at which the xylem can be damaged by cavitation. Next, depending on the strategy of the tree, transpiration is either reduced due to cavitation or to stomata closing to prevent cavitation (McDowell et al., 2008). During droughts, plants may reallocate carbon to roots instead of leaves or needles, thereby reducing their assimilation potential through reduced leaf area. Such seasonal changes in carbon allocation and phenology under drought are currently not explicitly handled in LPJ-GUESS because allocation occurs annually in the model (on the annual timescale, however, the ratio of leaves to fine roots is adjusted for water availability). Model inaccuracies in reproducing this type of vegetation phenology and hence the simulation of seasonal cycle of $\mathrm{CO}_{2}$ and water can lead to poorly simulated fluxes compared to observed ones. Future modelling efforts should focus on root dynamics, and include the effects of groundwater uptake and shifts in carbon allocation under water stress.

\section{Conclusions}

Variability in ecosystem carbon and water exchange is a key aspect of ecosystem functioning, but, in many cases, the drivers are poorly understood. Here, we showed that a DGVM, when adapted to the local conditions, can reproduce daily to seasonal variability in carbon and water exchange with high correlation coefficients. Similar to other studies, however, the model cannot reproduce interannual variability. We tried to identify the driving mechanisms of $\mathrm{IAV}_{\mathrm{cw}}$ by looking at systematic biases in the model output. By comparing the model to a long-term data set, we found that carbon assimilation during winter months at daily average temperatures below $0{ }^{\circ} \mathrm{C}$ is important for winter fluxes and not captured in the current parameterisation of the model, which might also apply to other, similar, models. Lowering the minimum temperature threshold for photosynthesis improved the simulation of winter GPP substantially, but did not greatly improve simulations of $\mathrm{IAV}_{\mathrm{cw}}$. In addition, we demonstrated that the modelled response to drought is too strong for this site, and that none of the water uptake formulations were consistently superior in reproducing the observed response of GPP and AET. AET and GPP during the 2003 heatwave were substantially underestimated by the model, even when assuming that plants have maximum water supply until the wilting point is reached. This result and the soil water curves suggest that at this site, access to deep water is crucial for the vegetation response to extreme drought. However, our understanding of $\mathrm{IAV}_{\mathrm{cw}}$ at the Loobos site still remains incomplete, as we were not able to disentangle the main drivers of $\mathrm{IAV}_{\mathrm{cw}}$ here. As future steps we suggest that, firstly, the representations of water uptake and root growth of plants need further attention in terms of model testing and parameterisation. This includes the implementation of a groundwater table and rooting access to it, and accounting for precipitation duration and intensity to make interception evaporation in winter more realistic. Secondly, estimating the amount of water stored deeper in the soil than the soil depth of common DGVMs 
may be crucial for simulating the drought response of vegetation even in areas such as the Loobos site, where this was not expected. Thirdly, we want to further explore the hypothesis that $\mathrm{IAV}_{\mathrm{cw}}$ is driven by short-term resource allocation of the vegetation. If past and current productivity (GPP) drive future productivity, for example via LAI changes, and these are influenced by environmental drivers and stressors such as temperature and droughts, modelling allocation and growth on a daily or monthly time step could be crucial. Because the process interactions underlying variability in ecosystem functioning are so complex that analyses with single factors, such as temperature or precipitation, often do not shed light on the mechanisms, we think that improvement of the process-based modelling and comparing these results with observations is an important complementary approach. Accurate reproduction of site-level fluxes with such models on seasonal to annual timescales is essential for our understanding of vegetation-climate interactions and for reducing uncertainties in future projections.

\section{The Supplement related to this article is available online at doi:10.5194/esd-6-485-2015-supplement.}

Acknowledgements. This work is part of the research programme Sustainable Earth, financed by the Netherlands Organisation for Scientific Research (NWO). T. Hickler acknowledges support from the LOEWE-Landesoffensive zur Entwicklung Wissenschaftlich-ökonomischer Exzellenz research funding programme of the Hessian State Ministry of Higher Education. The authors are grateful to J. Elbers, W. Jans and K. Fleischer for providing Loobos field data, to M. Forrest for model support, and to P. Rocha e Abreu and L. Mossink for assisting with photosynthesis measurements and raw data analysis. We thank I. Supit for fruitful discussions and valuable comments on the manuscript.

Edited by: S. Dekker

\section{References}

Abreu, P. M.: Loobos Scots Pine Forest Data Analysis 1997-2011, Dpt. Earth System Science \& Climate Change, Wageningen University, Wageningen, internal report, 2012.

Ahlström, A., Miller, P. A., and Smith, B.: Too early to infer a global NPP decline since 2000, Geophys. Res. Lett., 39, L15403, doi:10.1029/2012g1052336, 2012.

Arora, V. K. and Boer, G. J.: A parameterization of leaf phenology for the terrestrial ecosystem component of climate models, Glob. Change Biol., 11, 39-59, doi:10.1111/j.13652486.2004.00890.x, 2005.

Aubinet, M., Heinesch, B., and Longdoz, B.: Estimation of the carbon sequestration by a heterogeneous forest: night flux corrections, heterogeneity of the site and inter-annual variability, Glob. Change Biol., 8, 1053-1071, doi:10.1046/j.13652486.2002.00529.x, 2002.
Baldocchi, D., Falge, E., Gu, L., Olson, R., Hollinger, D., Running, S., Anthoni, P., Bernhofer, C., Davis, K., Evans, R., Fuentes, J., Goldstein, A., Katul, G., Law, B., Lee, X., Malhi, Y., Meyers, T., Munger, W., Oechel, W., Paw, K. T., Pilegaard, K., Schmid, H. P., Valentini, R., Verma, S., Vesala, T., Wilson, K., and Wofsy, S.: FLUXNET: a new tool to study the temporal and spatial variability of ecosystem-scale carbon dioxide, water vapor, and energy flux densities, B. Am. Meteorol. Soc., 82, 2415-2434, doi:10.1175/1520-0477(2001)082<2415:fantts> 2.3.co;2, 2001.

Berry, J. and Bjorkman, O.: Photosynthetic response and adaptation to temperature in higher plants, Annu. Rev. Plant Phys., 31, 491543, doi:10.1146/annurev.pp.31.060180.002423, 1980.

Bonan, G. B.: Forests and climate change: forcings, feedbacks, and the climate benefits of forests, Science, 320, 1444-1449, 2008.

Carrara, A., Kowalski, A. S., Neirynck, J., Janssens, I. A., Yuste, J. C., and Ceulemans, R.: Net ecosystem $\mathrm{CO}_{2}$ exchange of mixed forest in Belgium over 5 years, Agr. Forest Meteorol., 119, 209227, 2003.

Carrara, A., Janssens, I. A., Curiel Yuste, J., and Ceulemans, R.: Seasonal changes in photosynthesis, respiration and NEE of a mixed temperate forest, Agr. Forest Meteorol., 126, 15-31, 2004.

Cleland, E. E., Chuine, I., Menzel, A., Mooney, H. A., and Schwartz, M. D.: Shifting plant phenology in response to global change, Trends Ecol. Evol., 22, 357-365, 2007.

Collatz, G. J., Ball, J. T., Grivet, C., and Berry, J. A.: Physiological and environmental regulation of stomatal conductance, photosynthesis and transpiration: a model that includes a laminar boundary layer, Agr. Forest Meteorol., 54, 107-136, 1991.

Collatz, G. J., Ribas-Carbo, M., and Berry, J. A.: Coupled photosynthesis-stomatal conductance model for leaves of $\mathrm{C} 4$ plants, Aust. J. Plant Physiol., 19, 519-538, 1992.

Cox, P. M., Betts, R. A., Jones, C. D., Spall, S. A., and Totterdell, I. J.: Acceleration of global warming due to carbon-cycle feedbacks in a coupled climate model, Nature, 408, 184-187, 2000.

Dolman, A. J., Moors, E. J., and Elbers, J. A.: The carbon uptake of a mid latitude pine forest growing on sandy soil, Agr. Forest Meteorol., 111, 157-170, 2002.

Duursma, R. A., Kolari, P., Perämäki, M., Pulkkinen, M., Mäkelä, A., Nikinmaa, E., Hari, P., Aurela, M., Berbigier, P., Bernhofer, C., Grünwald, T., Loustau, D., Mölder, M., Verbeeck, H., and Vesala, T.: Contributions of climate, leaf area index and leaf physiology to variation in gross primary production of six coniferous forests across Europe: a model-based analysis, Tree Physiol., 29, 621-639, doi:10.1093/treephys/tpp010, 2009.

Elbers, J. A., Moors, E. J., and Jacobs, C. M. J.: Gemeten Actuele Verdamping Voor Twaalf Locaties in Nederland, Rapport/STOWA, nr. 2010-36, STOWA, Amersfoort, 2010.

Elbers, J. A., Jacobs, C. M. J., Kruijt, B., Jans, W. W. P., and Moors, E. J.: Assessing the uncertainty of estimated annual totals of net ecosystem productivity: a practical approach applied to a mid latitude temperate pine forest, Agr. Forest Meteorol., 151, 18231830, 2011.

Epron, D., Nouvellon, Y., and Ryan, M. G.: Introduction to the invited issue on carbon allocation of trees and forests, Tree Physiol., 32, 639-643, doi:10.1093/treephys/tps055, 2012.

Falge, E., Baldocchi, D., Tenhunen, J., Aubinet, M., Bakwin, P., Berbigier, P., Bernhofer, C., Burba, G., Clement, R., Davis, K. J., Elbers, J. A., Goldstein, A. H., Grelle, A., Granier, A., Guðmundsson, J., Hollinger, D., Kowalski, A. S., Katul, G., Law, 
B. E., Malhi, Y., Meyers, T., Monson, R. K., Munger, J. W., Oechel, W., Paw U, K. T., Pilegaard, K., Rannik, Ü., Rebmann, C., Suyker, A., Valentini, R., Wilson, K., and Wofsy, S.: Seasonality of ecosystem respiration and gross primary production as derived from FLUXNET measurements, Agr. Forest Meteorol., 113, 53-74, 2002.

Fatichi, S. and Ivanov, V. Y.: Interannual variability of evapotranspiration and vegetation productivity, Water Resour. Res., 50, 3275 3294, 2014.

Franklin, O., Johansson, J., Dewar, R. C., Dieckmann, U., McMurtrie, R. E., Brännström, ̊., and Dybzinski, R.: Modeling carbon allocation in trees: a search for principles, Tree Physiol., 32, 648666, doi:10.1093/treephys/tpr138, 2012.

Gea-Izquierdo, G., Mäkelä, A., Margolis, H., Bergeron, Y., Black, T. A., Dunn, A., Hadley, J., Paw U, K. T., Falk, M., Wharton, S., Monson, R., Hollinger, D. Y., Laurila, T., Aurela, M., McCaughey, H., Bourque, C., Vesala, T., and Berninger, F.: Modeling acclimation of photosynthesis to temperature in evergreen conifer forests, New Phytol., 188, 175-186, doi:10.1111/j.14698137.2010.03367.x, 2010.

Gerten, D., Schaphoff, S., Haberlandt, U., Lucht, W., and Sitch, S.: Terrestrial vegetation and water balance-hydrological evaluation of a dynamic global vegetation model, J. Hydrol., 286, 249-270, 2004

Goulden, M. L., Munger, J. W., Fan, S.-M., Daube, B. C., and Wofsy, S. C.: Exchange of carbon dioxide by a deciduous forest: response to interannual climate variability, Science, 271, 15761578, doi:10.1126/science.271.5255.1576, 1996.

Granier, A., Reichstein, M., Bréda, N., Janssens, I. A., Falge, E., Ciais, P., Grünwald, T., Aubinet, M., Berbigier, P., Bernhofer, C., Buchmann, N., Facini, O., Grassi, G., Heinesch, B., Ilvesniemi, H., Keronen, P., Knohl, A., Köstner, B., Lagergren, F., Lindroth, A., Longdoz, B., Loustau, D., Mateus, J., Montagnani, L., Nys, C., Moors, E., Papale, D., Peiffer, M., Pilegaard, K., Pita, G., Pumpanen, J., Rambal, S., Rebmann, C., Rodrigues, A., Seufert, G., Tenhunen, J., Vesala, T., and Wang, Q.: Evidence for soil water control on carbon and water dynamics in European forests during the extremely dry year: 2003, Agr. Forest Meteorol., 143, 123-145, 2007.

Haxeltine, A. and Prentice, I. C.: A general model for the lightuse efficiency of primary production, Funct. Ecol., 10, 551-561, 1996a.

Haxeltine, A. and Prentice, I. C.: BIOME3: an equilibrium terrestrial biosphere model based on ecophysiological constraints, resource availability, and competition among plant functional types, Global Biogeochem. Cy., 10, 693-709, doi:10.1029/96gb02344, 1996b.

Hickler, T., Eklundh, L., Seaquist, J. W., Smith, B., Ardö, J., Olsson, L., Sykes, M. T., and Sjöström, M.: Precipitation controls Sahel greening trend, Geophys. Res. Lett., 32, L21415, doi:10.1029/2005g1024370, 2005.

Hickler, T., Prentice, I. C., Smith, B., Sykes, M. T., and Zaehle, S.: Implementing plant hydraulic architecture within the LPJ Dynamic Global Vegetation Model, Global Ecol. Biogeogr., 15, 567-577, 2006.

Hickler, T., Vohland, K., Feehan, J., Miller, P. A., Smith, B., Costa, L., Giesecke, T., Fronzek, S., Carter, T. R., Cramer, W., Kühn, I., and Sykes, M. T.: Projecting the future distribution of European potential natural vegetation zones with a generalized, tree species-based dynamic vegetation model, Global Ecol. Biogeogr., 21, 50-63, doi:10.1111/j.1466-8238.2010.00613.x, 2012.

Higgins, S. I. and Scheiter, S.: Atmospheric $\mathrm{CO}_{2}$ forces abrupt vegetation shifts locally, but not globally, Nature, 488, 209-212, 2012.

Hui, D., Luo, Y., and Katul, G.: Partitioning interannual variability in net ecosystem exchange between climatic variability and functional change, Tree Physiol., 23, 433-442, doi:10.1093/treephys/23.7.433, 2003.

Huntingford, C. and Monteith, J. L.: The behaviour of a mixedlayer model of the convective boundary layer coupled to a big leaf model of surface energy partitioning, Bound.-Layer Meteorol., 88, 87-101, doi:10.1023/a:1001110819090, 1998.

Jackson, R. B., Canadell, J., Ehleringer, J. R., Mooney, H. A., Sala, O. E., and Schulze, E. D.: A global analysis of root distributions for terrestrial biomes, Oecologia, 108, 389-411, doi:10.1007/bf00333714, 1996.

Jacobs, C. M. J., Jacobs, A. F. G., Bosveld, F. C., Hendriks, D. M. D., Hensen, A., Kroon, P. S., Moors, E. J., Nol, L., SchrierUijl, A., and Veenendaal, E. M.: Variability of annual $\mathrm{CO}_{2}$ exchange from Dutch grasslands, Biogeosciences, 4, 803-816, doi:10.5194/bg-4-803-2007, 2007.

Jacobs, C. M. J., Moors, E. J., Elbers, J. A., Jans, W. W. P., and Kruijt, B.: Does Inter-Annual Variability of Net Ecosystem Exchange Exceed Uncertainty?, EGU General Assembly 2009, Vienna, 2009.

James, J. C., Grace, J., and Hoad, S. P.: Growth and photosynthesis of Pinus sylvestris at its altitudinal limit in Scotland, J. Ecol., 82, 297-306, 1994.

Jarvis, N. J.: Simple physics-based models of compensatory plant water uptake: concepts and eco-hydrological consequences, Hydrol. Earth Syst. Sci., 15, 3431-3446, doi:10.5194/hess-15-34312011, 2011.

Keenan, T. F., Baker, I., Barr, A., Ciais, P., Davis, K., Dietze, M., Dragoni, D., Gough, C. M., Grant, R., Hollinger, D., Hufkens, K., Poulter, B., McCaughey, H., Raczka, B., Ryu, Y., Schaefer, K., Tian, H., Verbeeck, H., Zhao, M., and Richardson, A. D.: Terrestrial biosphere model performance for inter-annual variability of land-atmosphere $\mathrm{CO}_{2}$ exchange, Glob. Change Biol., 18, 1971-1987, doi:10.1111/j.1365-2486.2012.02678.x, 2012.

KNMI Klimatologie: Seizoensoverzicht - Zomer 2003 (Juni, Juli, August): Zeer Warm, Zeer Zonnig en Zeer Droog, available at: http://www.knmi.nl/klimatologie/maand_en_ seizoensoverzichten/seizoen/zom03.html (last access: 12 June 2014), 2003.

KNMI Klimatologie: Seizoensoverzicht - Zomer 2005 (Juni, Juli, Augustus): Normale Temperatuur en Hoeveelheid Zonneschijn Maar Nat, available at: http://www.knmi.nl/klimatologie/maand en_seizoensoverzichten/seizoen/zom05.html (last access: 12 June 2014), 2005.

Kramer, K. and Hänninen, H.: The annual cycle of development of trees and process-based modelling of growth to scale up from the tree to the stand, in: Phenology of Ecosystem Processes, edited by: Noormets, A., Springer, New York, 201-227, 2009.

Kramer, K., Buiteveld, J., Forstreuter, M., Geburek, T., Leonardi, S., Menozzi, P., Povillon, F., Schelhaas, M. J., Teissier du Cros, E., Vendramin, G. G., and van der Werf, D. C.: Bridging the gap between ecophysiological and genetic knowledge to assess the 
adaptive potential of European beech, Ecol. Model., 216, 333353, 2008.

Kruijt, B., Jacobs, C., Moors, E., Elbers, J., Randow, C. v., Saleska, S., and Baldocchi, D.: [Presentation] Interannual variability in Net Ecosystem Exchange: is it deterministic, chaotic or random?, ICDC8: 8th International Carbon Dioxide Conference, held 1319 September 2009, in Jena (Germany), 2009.

Lagergren, F. and Lindroth, A.: Transpiration response to soil moisture in pine and spruce trees in Sweden, Agr. Forest Meteorol., 112, 67-85, doi:10.1016/S0168-1923(02)00060-6, 2002.

Larcher, W.: Physiological Plant Ecology, Springer, Berlin, 1980.

Leemans, R. and Prentice, I. C.: FORSKA, a general forest succession model, Institute of Ecological Botany, Uppsala University, Uppsala, Sweden, PhD, 70 pp., 1989.

Lenton, T. M., Held, H., Kriegler, E., Hall, J. W., Lucht, W., Rahmstorf, S., and Schellnhuber, H. J.: Tipping elements in the Earth's climate system, P. Natl. Acad. Sci. USA, 105, 17861793, doi:10.1073/pnas.0705414105, 2008.

Linder, S. and Troeng, E.: Photosynthesis and transpiration of 20year-old scots pine, in: Structure and function of northern coniferous forests-an ecosystem study, edited by: Persson, T., Ecological Bulletins, 32, 165-181, 1980.

Litton, C. M., Raich, J. W., and Ryan, M. G.: Carbon allocation in forest ecosystems, Glob. Change Biol., 13, 2089-2109, doi:10.1111/j.1365-2486.2007.01420.x, 2007.

Luyssaert, S., Janssens, I. A., Sulkava, M., Papale, D., Dolman, A. J., Reichstein, M., Hollmén, J., Martin, J. G., Suni, T., Vesala, T., Loustau, D., Law, B. E., and Moors, E. J.: Photosynthesis drives anomalies in net carbon-exchange of pine forests at different latitudes, Glob. Change Biol., 13, 2110-2127, doi:10.1111/j.13652486.2007.01432.x, 2007.

McDowell, N., Pockman, W. T., Allen, C. D., Breshears, D. D., Cobb, N., Kolb, T., Plaut, J., Sperry, J., West, A., Williams, D. G., and Yepez, E. A.: Mechanisms of plant survival and mortality during drought: why do some plants survive while others succumb to drought?, New Phytol., 178, 719-739, doi:10.1111/j.1469-8137.2008.02436.x, 2008.

Medlyn, B. E., Zaehle, S., De Kauwe, M. G., Walker, A. P., Dietze, M. C., Hanson, P. J., Hickler, T., Jain, A. K., Luo, Y., Parton, W., Prentice, I. C., Thornton, P. E., Wang, S., Wang, Y.-P., Weng, E., Iversen, C. M., McCarthy, H. R., Warren, J. M., Oren, R., and Norby, R. J.: Using ecosystem experiments to improve vegetation models, Nature Climate Change, 5, 528-534, 2015.

Moors, E. J.: Water Use of Forests in the Netherlands, Vrije Universiteit Amsterdam, the Netherlands, Vrije Universiteit Amsterdam, Amsterdam The Netherlands, 290 pp., 2012.

Moors, E. J., Elbers, J. A., Hutjes, R. W. A., Jacobs, C., Jans, W. W. P., Kruijt, B., Stolk, P., ter Maat, H., Vermeulen, M., Abreu, P., and Dolman, A. J.: Inter-annual variability of carbon exchange and extreme events at the Loobos pine forest, in preparation, 2015.

Morales, P., Sykes, M. T., Prentice, I. C., Smith, P., Smith, B., Bugmann, H., Zierl, B., Friedlingstein, P., Viovy, N., Sabaté, S., Sánchez, A., Pla, E., Gracia, C. A., Sitch, S., Arneth, A., and Ogee, J.: Comparing and evaluating process-based ecosystem model predictions of carbon and water fluxes in major European forest biomes, Glob. Change Biol., 11, 2211-2233, doi:10.1111/j.1365-2486.2005.01036.x, 2005.
Naeem, S.: Ecosystem consequences of biodiversity loss: the evolution of a paradigm, Ecology, 83, 1537-1552, doi:10.1890/00129658(2002)083[1537:ecoblt]2.0.co;2, 2002.

Peylin, P., Bousquet, P., Le Quéré, C., Sitch, S., Friedlingstein, P., McKinley, G., Gruber, N., Rayner, P., and Ciais, P.: Multiple constraints on regional $\mathrm{CO}_{2}$ flux variations over land and oceans, Global Biogeochem. Cy., 19, GB1011, doi:10.1029/2003gb002214, 2005.

Pitman, A. J., de Noblet-Ducoudré, N., Cruz, F. T., Davin, E. L., Bonan, G. B., Brovkin, V., Claussen, M., Delire, C., Ganzeveld, L., Gayler, V., van den Hurk, B. J. J. M., Lawrence, P. J., van der Molen, M. K., Müller, C., Reick, C. H., Seneviratne, S. I., Strengers, B. J., and Voldoire, A.: Uncertainties in climate responses to past land cover change: first results from the LUCID intercomparison study, Geophys. Res. Lett., 36, L14814, doi:10.1029/2009g1039076, 2009.

Rammig, A., Jupp, T., Thonicke, K., Tietjen, B., Heinke, J., Ostberg, S., Lucht, W., Cramer, W., and Cox, P.: Estimating the risk of Amazonian forest dieback, New Phytol., 187, 694-706, doi:10.1111/j.1469-8137.2010.03318.x, 2010.

Reichstein, M., Falge, E., Baldocchi, D., Papale, D., Aubinet, M., Berbigier, P., Bernhofer, C., Buchmann, N., Gilmanov, T., Granier, A., Grünwald, T., Havránková, K., Ilvesniemi, H., Janous, D., Knohl, A., Laurila, T., Lohila, A., Loustau, D., Matteucci, G., Meyers, T., Miglietta, F., Ourcival, J.-M., Pumpanen, J., Rambal, S., Rotenberg, E., Sanz, M., Tenhunen, J., Seufert, G., Vaccari, F., Vesala, T., Yakir, D., and Valentini, R.: On the separation of net ecosystem exchange into assimilation and ecosystem respiration: review and improved algorithm, Glob. Change Biol., 11, 1424-1439, doi:10.1111/j.1365-2486.2005.001002.x, 2005.

Sandström, F., Petersson, H., Kruys, N., and Ståhl, G.: Biomass conversion factors (density and carbon concentration) by decay classes for dead wood of Pinus sylvestris, Picea abies and Betula spp. in boreal forests of Sweden, Forest Ecol. Manag., 243, 19-27, doi:10.1016/j.foreco.2007.01.081, 2007.

Schelhaas, M. J., Nabuurs, G. J., Jans, W. W. P., Moors, E. J., Sabaté, S., and Daamen, W. P.: Closing the carbon budget of a Scots pine forest in the Netherlands, Climatic Change, 67, 309328, 2004.

Schurgers, G., Hickler, T., Miller, P. A., and Arneth, A.: European emissions of isoprene and monoterpenes from the Last Glacial Maximum to present, Biogeosciences, 6, 2779-2797, doi:10.5194/bg-6-2779-2009, 2009.

Sevanto, S., Suni, T., Pumpanen, J., Grönholm, T., Kolari, P., Nikinmaa, E., Hari, P., and Vesala, T.: Wintertime photosynthesis and water uptake in a boreal forest, Tree Physiol., 26, 749-757, doi:10.1093/treephys/26.6.749, 2006.

Sierra, C. A., Loescher, H. W., Harmon, M. E., Richardson, A. D., Hollinger, D. Y., and Perakis, S. S.: Interannual variation of carbon fluxes from three contrasting evergreen forests: the role of forest dynamics and climate, Ecology, 90, 2711-2723, doi:10.1890/08-0073.1, 2009.

Sitch, S., Smith, B., Prentice, I. C., Arneth, A., Bondeau, A., Cramer, W., Kaplan, J. O., Levis, S., Lucht, W., Sykes, M. T., Thonicke, K., and Venevsky, S.: Evaluation of ecosystem dynamics, plant geography and terrestrial carbon cycling in the LPJ dynamic global vegetation model, Glob. Change Biol., 9, 161-185, 2003. 
Sitch, S., Huntingford, C., Gedney, N., Levy, P. E., Lomas, M., Piao, S. L., Betts, R., Ciais, P., Cox, P., Friedlingstein, P., Jones, C. D., Prentice, I. C., and Woodward, F. I.: Evaluation of the terrestrial carbon cycle, future plant geography and climate-carbon cycle feedbacks using five Dynamic Global Vegetation Models (DGVMs), Glob. Change Biol., 14, 2015-2039, doi:10.1111/j.1365-2486.2008.01626.x, 2008.

Sitch, S., Friedlingstein, P., Gruber, N., Jones, S. D., MurrayTortarolo, G., Ahlström, A., Doney, S. C., Graven, H., Heinze, C., Huntingford, C., Levis, S., Levy, P. E., Lomas, M., Poulter, B., Viovy, N., Zaehle, S., Zeng, N., Arneth, A., Bonan, G., Bopp, L., Canadell, J. G., Chevallier, F., Ciais, P., Ellis, R., Gloor, M., Peylin, P., Piao, S. L., Le Quéré, C., Smith, B., Zhu, Z., and Myneni, R.: Recent trends and drivers of regional sources and sinks of carbon dioxide, Biogeosciences, 12, 653679, doi:10.5194/bg-12-653-2015, 2015.

Smith, B., Prentice, I. C., and Sykes, M. T.: Representation of vegetation dynamics in the modelling of terrestrial ecosystems: comparing two contrasting approaches within European climate space, Global Ecol. Biogeogr., 10, 621-637, doi:10.1046/j.1466822X.2001.t01-1-00256.x, 2001.

Smith, N. G. and Dukes, J. S.: Plant respiration and photosynthesis in global-scale models: incorporating acclimation to temperature and $\mathrm{CO}_{2}$, Glob. Change Biol., 19, 45-63, doi:10.1111/j.13652486.2012.02797.x, 2013.

Suni, T., Berninger, F., Markkanen, T., Keronen, P., Rannik, Ü., and Vesala, T.: Interannual variability and timing of growing-season $\mathrm{CO}_{2}$ exchange in a boreal forest, J. Geophys. Res., 108, 4265, doi:10.1029/2002jd002381, 2003a.

Suni, T., Berninger, F., Vesala, T., Markkanen, T., Hari, P., Mäkelä, A., Ilvesniemi, H., Hänninen, H., Nikinmaa, E., Huttula, T., Laurila, T., Aurela, M., Grelle, A., Lindroth, A., Arneth, A., Shibistova, O., and Lloyd, J.: Air temperature triggers the recovery of evergreen boreal forest photosynthesis in spring, Glob. Change Biol., 9, 1410-1426, doi:10.1046/j.13652486.2003.00597.x, 2003b.

Teskey, R. O., Whitehead, D., and Linder, S.: Photosynthesis and carbon gain by pines, Ecol. Bull., in: Environmental constraints on the structure and productivity of pine forest ecosystems: a comparative analysis, edited by: Gholz, H. L., Linder, S., and McMurtrie, R. E., Ecological Bulletins, 43, 35-49, 1994.

Teuling, A. J., Seneviratne, S. I., Stockli, R., Reichstein, M., Moors, E., Ciais, P., Luyssaert, S., van den Hurk, B., Ammann, C., Bernhofer, C., Dellwik, E., Gianelle, D., Gielen, B., Grunwald, T., Klumpp, K., Montagnani, L., Moureaux, C., Sottocornola, M., and Wohlfahrt, G.: Contrasting response of European forest and grassland energy exchange to heatwaves, Nat. Geosci., 3, 722727,2010

Thomas, S. C. and Martin, A. R.: Carbon content of tree tissues: a synthesis, Forests, 3, 332-352, 2012.

van den Hurk, B. J. J. M., Viterbo, P., and Los, S. O.: Impact of leaf area index seasonality on the annual land surface evaporation in a global circulation model, J. Geophys. Res., 108, 4191, doi:10.1029/2002jd002846, 2003. van der Werf, G. W., Sass-Klaassen, U. G. W., and Mohren, G. M. J.: The impact of the 2003 summer drought on the intra-annual growth pattern of beech (Fagus sylvatica L.) and oak (Quercus robur L.) on a dry site in the Netherlands, Dendrochronologia, 25, 103-112, 2007.

Verbeeck, H., Peylin, P., Bacour, C., Bonal, D., Steppe, K., and Ciais, P.: Seasonal patterns of $\mathrm{CO}_{2}$ fluxes in Amazon forests: fusion of eddy covariance data and the ORCHIDEE model, J. Geophys. Res.-Biogeo., 116, G02018, doi:10.1029/2010jg001544, 2011.

Weber, U., Jung, M., Reichstein, M., Beer, C., Braakhekke, M. C., Lehsten, V., Ghent, D., Kaduk, J., Viovy, N., Ciais, P., Gobron, N., and Rödenbeck, C.: The interannual variability of Africa's ecosystem productivity: a multi-model analysis, Biogeosciences, 6, 285-295, doi:10.5194/bg-6-285-2009, 2009.

Williams, C. A., Hanan, N. P., Baker, I., Collatz, G. J., Berry, J., and Denning, A. S.: Interannual variability of photosynthesis across Africa and its attribution, J. Geophys. Res., 113, G04015, doi:10.1029/2008jg000718, 2008.

Wolkovich, E. M., Cook, B. I., Allen, J. M., Crimmins, T. M., Betancourt, J. L., Travers, S. E., Pau, S., Regetz, J., Davies, T. J., Kraft, N. J. B., Ault, T. R., Bolmgren, K., Mazer, S. J., McCabe, G. J., McGill, B. J., Parmesan, C., Salamin, N., Schwartz, M. D., and Cleland, E. E.: Warming experiments underpredict plant phenological responses to climate change, Nature, 485, 494-497, doi:10.1038/nature11014, 2012.

Wramneby, A., Smith, B., Zaehle, S., and Sykes, M. T.: Parameter uncertainties in the modelling of vegetation dynamics-Effects on tree community structure and ecosystem functioning in European forest biomes, Ecol. Model., 216, 277-290, 2008.

Wramneby, A., Smith, B., and Samuelsson, P.: Hot spots of vegetation-climate feedbacks under future greenhouse forcing in Europe, J. Geophys. Res.-Atmos., 115, D21119, doi:10.1029/2010jd014307, 2010.

Yamamoto, S., Murayama, S., And, N. S., and Kondo, H.: Seasonal and inter-annual variation of $\mathrm{CO}_{2}$ flux between a temperate forest and the atmosphere in Japan, Tellus B, 51, 402-413, doi:10.1034/j.1600-0889.1999.00020.x, 1999.

Yuan, W., Luo, Y., Richardson, A. D., Oren, R., Luyssaert, S., Janssens, I. A., Ceulemans, R., Zhou, X., Grünwald, T., Aubinet, M., Berhofer, C., Baldocchi, D. D., Chen, J., Dunn, A. L., Deforest, J. L., Dragoni, D., Goldstein, A. H., Moors, E., Munger, J. W., Monson, R. K., Suyker, A. E., Starr, G., Scott, R. L., Tenhunen, J., Verma, S. B., Vesala, T., and Wofsy, S. T. E.: Latitudinal patterns of magnitude and interannual variability in net ecosystem exchange regulated by biological and environmental variables, Glob. Change Biol., 15, 2905-2920, doi:10.1111/j.1365-2486.2009.01870.x, 2009.

Zaehle, S., Sitch, S., Smith, B., and Hatterman, F.: Effects of parameter uncertainties on the modeling of terrestrial biosphere dynamics, Global Biogeochem. Cy., 19, GB3020, doi:10.1029/2004gb002395, 2005. 